\title{
The influence of socioeconomic factors on traditional knowledge: a cross scale comparison of palm use in northwestern South America
}

\author{
Narel Y. Paniagua-Zambrana ${ }^{1}$, Rodrigo Camara-Lerét ${ }^{2}$, Rainer W. Bussmann $^{3}$ and Manuel J. Macía ${ }^{2}$
}

\begin{abstract}
We explored the power of 14 socioeconomic factors for predicting differences in traditional knowledge about palms (Arecaceae) at the personal, household, and regional levels in 25 locations in the Amazon, Andes, and Chocó of northwestern South America. Using semistructured interviews, we gathered data on palm uses from 2050 informants in 53 communities and four countries (Colombia, Ecuador, Peru, and Bolivia ). We performed multilevel statistical analyses, which showed that the influence of each socioeconomic factor differed depending on whether the analysis was performed on the overall palm knowledge or on individual use categories. At the general palm knowledge level, gender was the only factor that had a significant association in all five subregions, and showed that men had more knowledge than women, and age had a positive significant association only in the lowlands. Most of the analyzed socioeconomic factors had a greater influence on the lowland ecoregions of the Amazon and Chocó, although there were mixed trends in these ecoregions. Our results show that there are no regional patterns in the predictive power of socioeconomic factors and that their influence on palm-use knowledge is highly localized. We can conclude that (1) conservation strategies of traditional knowledge of palm use in the region should be developed mainly at the local level, and (2) large-scale comparable ethnoecological studies are necessary to understand indigenous communities' livelihoods at different scales.
\end{abstract}

Key Words: Arecaceae; indigenous communities; livelihood; quantitative ethnobotany; traditional ecological knowledge; tropical rainforests

\section{INTRODUCTION}

Traditional knowledge (TK) is an important component in improving livelihoods (Reyes-García et al. 2008), management of natural resources (Mackinson and Nottestad 1998, Berkes et al. 2000, Huntington 2000), and practices related to the protection of ecosystems and species (Shackeroff and Campbell 2007). This type of knowledge is developed by local communities through experiences of adapting to their environment. It is dynamic and continuously modified, but very little attention has been focused on understanding the changes resulting from adaptations to new environmental, cultural, social, and economic conditions (Gómez-Baggethun and Reyes-García 2013). Such changes may lead to the loss of local knowledge systems (Benz et al. 2000, Brosi et al. 2007), which could result in a reduced ability to cope with environmental changes.

In the last 15 years, a large number of studies have sought to understand how social, economic, cultural, environmental, and geographical factors influence the TK about plants at small scales. Factors such as gender, age, ethnicity, birthplace, and level of education have been identified as important on an individual level (Luoga et al. 2000, Byg 2004, Byg and Balslev 2006, Paniagua Zambrana et al. 2007). Family size, integration into the market economy (e.g., sale of animals and agricultural products), or amount of material goods at the family level (e.g., possessions of farm animals, tools, and transport) have been linked to the household level (Byg and Balslev 2001, 2004, Reyes-García et al. 2005). Access to commercial centers and to health, education, electricity, or water, as well as land tenure systems and settlement history, have shown a greater relevance at the community level (Takasaki et al. 2001, Byg et al. 2007, Vandebroek 2010). Although many of these studies might reflect the specific relationship that each culture has with natural resources, without a unifying theory or common research method we cannot discern whether such findings reflect patterns and behaviors that are similar, or even identical, between different cultures and broader scales (Alburquerque and Medeiros 2012). Several studies have used meta-analyses to analyze large-scale usage patterns of plants (Moerman et al. 1999, Molares and Ladio 2009, SaslisLagoudakis et al. 2011), although comparisons are difficult to make given the diversity of the objectives and methods employed.

Evidence of these patterns can serve in generating strategies for the preservation of knowledge at regional scales, without neglecting characteristics of each region and the dynamic nature of knowledge. If levels of TK can be predicted from socioeconomic data, conservation actions could focus better on the population sectors that have more knowledge and are facing greater risks of loss. To compare the influence of these factors on the knowledge of multiple cultures at communities and individuals levels, research needs to be designed very carefully to allow the elucidation of common patterns (Alburquerque and Medeiros 2012).

In this study, we examine the influence of socioeconomic variables on TK across different ecoregions (Amazon, Andes, and Chocó) of northwestern South America, using a standardized interview protocol. Specifically, we evaluate the predictive power of 14 socioeconomic factors previously identified as being important in determining knowledge differences at the personal level (gender, age, ethnicity, education, language spoken, migration status, time in residence), and at the household level (size of family, tenure of farm animals, farm size, tools, transport, house size, house constructions materials). We use palms (Arecaceae) as a model group because of their extraordinary importance in the livelihoods of indigenous and nonindigenous populations in the region (Balick 1984, Prance et al. 1987, Phillips and Gentry 1993, Galeano 2000, Macía 2004, Lawrence et al. 2005, Brokamp et al.

${ }^{1}$ Herbario Nacional de Bolivia, Universidad Mayor de San Andrés, Cota Cota, La Paz, Bolivia, ${ }^{2}$ Departamento de Biología, Área de Botánica, Universidad Autónoma de Madrid, Spain, ${ }^{3}$ William L. Brown Center, Missouri Botanical Garden, St. Louis, Missouri, USA 
Table 1. Distribution of the 2050 interviews conducted in 15 localities with 53 communities in northwestern South America (Colombia, Ecuador, Peru, and Bolivia) by gender and ethnicity in five age groups. Additional data on distribution in other evaluated factors are shown in Appendix 2.

\begin{tabular}{|c|c|c|c|c|c|c|}
\hline Attributes & Northern Amazon & Southern Amazon & Northern Andes & Southern Andes & Chocó & Total \\
\hline $\begin{array}{l}\text { Number of } \\
\text { communities } \\
\text { Gender }\end{array}$ & 11 & 23 & 5 & 8 & 6 & 53 \\
\hline Female & 147 & 413 & 194 & 119 & 160 & 1033 \\
\hline Male & 153 & 415 & 148 & 149 & 152 & 1017 \\
\hline \multicolumn{7}{|l|}{ Ethnicity } \\
\hline Indigenous & 299 & 438 & 167 & 252 & 138 & 1294 \\
\hline Mestizo & 1 & 390 & 172 & 16 & 87 & 666 \\
\hline Afro-American & - & - & 3 & - & 87 & 90 \\
\hline \multicolumn{7}{|l|}{ Age (years) } \\
\hline $18-30$ & 86 & 235 & 110 & 58 & 91 & 580 \\
\hline $31-40$ & 79 & 190 & 75 & 63 & 64 & 471 \\
\hline $41-50$ & 55 & 175 & 53 & 73 & 50 & 406 \\
\hline $51-60$ & 36 & 106 & 42 & 36 & 53 & 273 \\
\hline$>60$ & 44 & 122 & 62 & 38 & 54 & 320 \\
\hline
\end{tabular}

2011), and because many species of useful palms show similar use patterns that are shared between different cultures and regions (Macía et al. 2011, Cámara-Leret et al. 2014). In addition, palms are conspicuous and abundant in many tropical rainforest habitats, and their taxonomy, diversity, and distribution are well known (Henderson et al. 1995, Borchsenius et al. 1998, Moraes 2004, Pintaud et al. 2008, Galeano and Bernal 2010). To our knowledge, this is the first attempt to test the influence of socioeconomic factors on TK about a keystone plant family in South America or any other large region of the world, across large spatial scales and different cultural groups.

\section{METHODS}

\section{Study region}

Research was conducted in the Amazon and Andes of Colombia, Ecuador, Peru, and Bolivia, as well as the Chocó of Colombia and Ecuador. We interviewed participants in 25 localities inhabited by indigenous, Afro-American, mestizo, and multiethnic groups (Fig. 1, Appendix 1). The Amazon ecoregion was defined as the lowlands to the east of the Andes, below $1000 \mathrm{~m}$ elevation (e.g., Renner et al. 1990, Jørgensen and León-Yánez 1999). The Andes ecoregion was defined as the humid montane forests on both slopes of the Andes, above $1000 \mathrm{~m}$, including the inter-Andean valleys of Bolivia that receive less precipitation (Beck et al. 1993). The Chocó ecoregion was defined as the humid forests along the Pacific coast of Colombia and northern Ecuador, below $1000 \mathrm{~m}$. Localities were selected in each ecoregion to have a uniform ethnic composition, varying degrees of accessibility to markets, and access to mature forests for harvesting palms (Appendix 1). Localities included more than one community if the number of people interviewed in a single community was less than 87 (seven expert informants plus 80 general informants), as defined in our research protocol (Paniagua-Zambrana et al. 2010). The analyses were conducted in five subregions. We subdivided the Amazon ecoregion into two subregions: the northwestern Amazon, with four localities in Colombia and Ecuador, and the southwestern Amazon, with 10 localities in Peru and Bolivia. The Andes ecoregion was subdivided into the northwestern Andes, with four localities in Colombia and Ecuador, and the southwestern Andes, with five localities in Peru and Bolivia. The Chocó ecoregion included three localities in Colombia and northwestern Ecuador (Fig. 1, Appendix 1).

\section{Data collection}

Ethnobotanical data and socioeconomic information were gathered through semistructured interviews using a standardized protocol (Paniagua-Zambrana et al. 2010, Cámara-Leret et al. 2012). Prior to starting the interviews, we obtained the necessary permits and established informed consent with the communities and informants. From March 2010 to December 2011, we collected ethnobotanical information with two types of informants: experts, of whom we interviewed 5-7 in each community ( $n=159)$, and general informants, of whom we interviewed 10-89 in each community $(n=1891)$. Experts were selected by consensus of community members during a communal meeting. General informants were selected by researchers to achieve a balanced representation of gender and age classes within the localities. We divided informants into five age classes $(18-30,31-40,41-50,51-60$, and $>60$ years old) to achieve an equal representation of all ages. Within the age classes, approximately $50 \%$ of the people we interviewed were women and $50 \%$ were men (Table 1, Appendix 2). We first interviewed the expert informants through "walks in the woods," during which we documented all palm species that grew in the surroundings of the communities, collected vouchers, identified the species, documented their uses, and recorded their local names. These vernacular names were later used in the interviews with the general informants. We then conducted semistructured interviews with the general informants while visiting them in their homes. We asked each person about each of the species that was reported during interviews with the experts. Interviews were conducted in Spanish. In cases where an informant did not speak Spanish, the interviews were conducted with the help of local interpreters. We gathered information from all informants regarding 14 
Fig. 1. Map of the study area in northwestern South America showing ecoregions (Amazon, Andes, Chocó), countries (Colombia, Ecuador, Peru, Bolivia), and communities where palm ethnobotanical data were recorded.

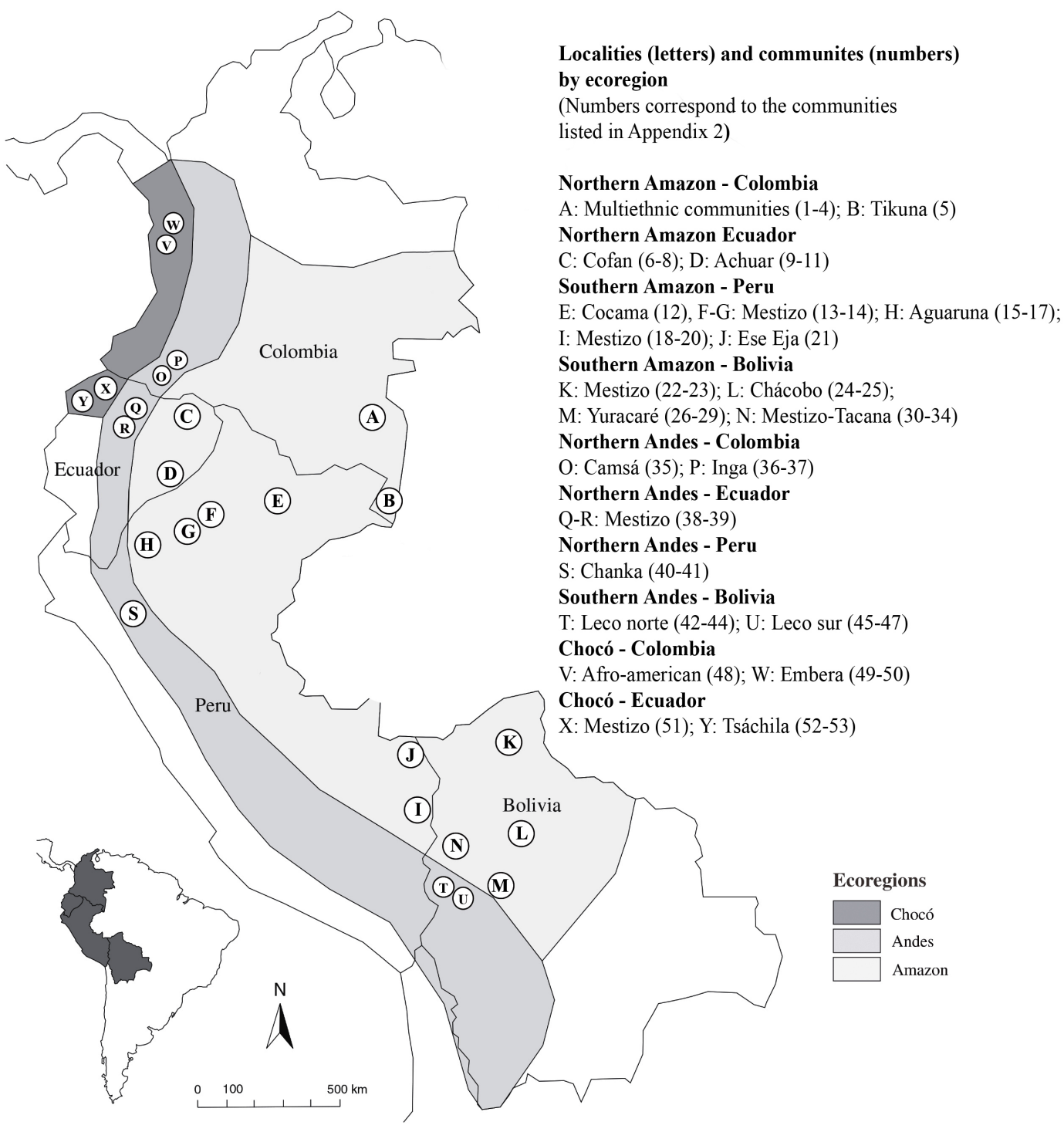

socioeconomic variables concerning personal data (seven variables: gender, age, ethnicity, education, languages spoken, migration status, time in residence) and household data (seven variables: size of family, tenure of farm animals, farm size, tools, transports, house size, house constructions materials) (Table 2). Palms were identified in the field wherever possible, and vouchers were collected only if the onsite identification needed additional confirmation. Voucher specimens were deposited in the herbaria AAU, AMAZ, COL, LPB, and QCA (herbarium acronyms according to Thiers [2013]).

\section{Data analysis}

We grouped the socioeconomic data obtained in the interviews into three types of variables: nominal (gender, ethnicity, languages spoken), ordinal (migration status, tenure of farm animals, tools, transports, house construction materials), and continuous (age, size of family, educations, time in residence, farm size, house size) (Table 2).

To determine the influence of socioeconomic factors on TK levels, we calculated two different indicators of knowledge: (1) palm usereports, representing the sum of all palm uses reported by an informant for all species known by that person, and (2) useful palm species, representing the sum of all useful species an informant knew. The term "use-report" is defined as an individual palm use mentioned by an informant. For this purpose, we use the definition of "palm-use" given by Macía et al. (2011), which defines it as the use associated to a use category and use subcategory for a specific plant part. In an initial analysis, both indicators showed strong correlations (northern Amazon $r=0.87$; 
Table 2. Description of 14 socioeconomic variables gathered from 2050 informants in 25 localities of northwestern South America (Colombia, Ecuador, Peru, and Bolivia).

\begin{tabular}{|c|c|c|}
\hline Independent variable & Variable type & Levels \\
\hline Gender & Nominal & (1) Men; (2) Women \\
\hline Age & Continuous & Between 18 and 102 years \\
\hline Ethnicity & Nominal & (1) Indigenous; (2) Mestizo; (3) Afro-American \\
\hline Size of family (number of children) & Continuous & Between 0 and 20 \\
\hline Education (years) & Continuous & Between 0 and 24 years \\
\hline Languages spoken & Nominal & (1) Only native language; (2) Only Spanish; (3) Native language and Spanish \\
\hline Migratory status & Ordinal & $\begin{array}{l}\text { (1) Nonmigrant; (2) Migrant from other ethnic group in the same ecoregion; (3) } \\
\text { Migrant from other ecoregion }\end{array}$ \\
\hline Time in residence (years) & Continuous & Between 0.17 and 102 years \\
\hline Farm animals & Ordinal & (1) No animals; (2) Subsistence livestock; (3) Commercial livestock \\
\hline Farm size (ha) & Continuous & Between 0 and 50 ha \\
\hline Tools & Ordinal & $\begin{array}{l}\text { 1) Low cost (e.g., machetes, axes, bows and arrows, fishhooks, traditional agricultural } \\
\text { tools); (2) Average cost (e.g., fishing nets, carts, shotguns/rifles, plow, mechanical seed } \\
\text { distributors); (3) High cost (e.g., fumigators, tractors, chainsaws, water pumps) }\end{array}$ \\
\hline Transport & Ordinal & $\begin{array}{l}\text { (1) No transport; (2) No fuel consumption (e.g., canoe, bicycle); (3) Low fuel } \\
\text { consumption (e.g., motorbike, small outboard motor); (4) High fuel consumption (e.g., } \\
\text { truck, large outboard motor) }\end{array}$ \\
\hline House size $\left(\mathrm{m}^{2}\right)$ & Continuous & Between 8 and $936 \mathrm{~m}^{2}$ \\
\hline House construction materials & Ordinal & $\begin{array}{l}\text { (1) Local plant materials } \geq 50 \% \text {; (2) Mixed material } \geq 50 \% \text {; (3) Foreign commercial } \\
\text { materials } \geq 50 \%\end{array}$ \\
\hline Locality & Nominal & 25 \\
\hline
\end{tabular}

southern Amazon $r=0.79$; Chocó $r=0.84$; northern Andes $r=$ 0.64; southern Andes $r=0.82$ ). For this reason, we decided to use only the number of useful palm species as the dependent variable in all subsequent analyses.

All palm uses and useful species reported in the interviews were classified into 10 use categories following the Economic Botany Data Collection Standard (Cook 1995), with some modifications proposed by Macía et al. (2011): Animal food, Construction, Cultural, Environmental, Fuel, Human food, Medicinal and veterinary, Toxic, Utensils and tools, and Other uses (including indirect uses, especially the use of beetle larvae that develop in rotting trunks).

To describe and compare TK in relation to the 14 socioeconomic factors evaluated in the five subregions studied, we first conducted a descriptive analysis of the whole data set using a MANOVA and its corresponding post hoc Tukey test for the eight categorical factors (categorical variables; levels with less than 10 replicas were not included in the analyses) and Pearson correlations for the six continuous factors (continuous variables) (Table 2). Based on this analysis, we selected the socioeconomic factors that were included in subsequent analyses. We excluded those categorical variables that showed significant differences between their different levels, and excluded continuous variables with $r<0.05$.

To assess the variations in TK in the five subregions, we implemented a statistical multilevel model of the effects of socioeconomic factors on the knowledge of useful palm species. Multilevel models (also known as hierarchical linear models or mixed models) are an extension of linear regression that can be used to account for clustered sampling designs and to explicitly model contextual effects (Bryk and Raudenbush 1992, Goldstein 2003, Gray et al. 2008). The dependent variable for our analyses was the number of useful palm species, and the independent variables with fixed effect were the socioeconomic factors that were selected in each subregion based on the initial descriptive analysis. These were added as a random factor to the categorical variable-locality. The one-level random-intercept model that we constructed had the following formula:

$$
Y_{i j}=\gamma_{00}+\left(\beta X_{i} \ldots\right)+\left(\tau X_{i}^{\prime} \ldots . .\right)+r_{0 j}+\sigma_{L}+e_{i j}
$$

where $Y_{i j}$ is the independent variable; $\gamma_{00}$ is the common intercept; $\beta$ and $\tau$ are the respective coefficients of the continuous variables $X_{i}$ and categorical $\mathrm{X}^{\prime} ; r_{0 j}$ has a normal distribution with median 0 ; standard deviation $\sigma_{L}$ represents the variability of the 25 localities studies; and $e_{i j}$ is the error or residual for each of the interviewees. The same analyses were applied in each of the 10 use categories. All analyses were performed in R 3.0.1 (R Development Core Team 2014).

\section{RESULTS}

\section{Descriptive analysis of socioeconomic variables and palm-use knowledge}

Localities in the Amazon showed the greatest palm-use knowledge, followed by the Chocó and Andes (Table 3). Northern Amazonian localities reported the highest values regarding both the number of use-reports and useful palm species, and northern Andean localities had the lowest values.

The following patterns resulting from the descriptive and comparative analyses are shown in Table 3. In all subregions except in the localities of the southern Amazon, men knew more than women. Age showed a positive relationship with knowledge in all subregions, although in most cases, the relationship was weak $(r<0.20)$. With regard to ethnicity, we found that indigenous people had more knowledge than mestizos in both the southern Amazon and the Chocó, while mestizos had more knowledge in 
Table 3. Descriptive statistics of palm-use knowledge in the five subregions evaluated in northwestern South America. Letters (a, b, c) indicate significantly different means based on an unifactorial Anova test $(p<0.05)$. $(*)$ Levels with less than 10 replicas, not included in the analyses.

\begin{tabular}{|c|c|c|c|c|c|c|c|c|c|c|}
\hline & \multicolumn{2}{|c|}{ Northern Amazon } & \multicolumn{2}{|c|}{ Southern Amazon } & \multicolumn{2}{|r|}{ Chocó } & \multicolumn{2}{|c|}{ Northern Andes } & \multicolumn{2}{|c|}{ Southern Andes } \\
\hline & $N$ & Mean $\pm \mathrm{SD}$ & $N$ & Mean \pm SD & $N$ & Mean \pm SD & $N$ & Mean \pm SD & $N$ & Mean \pm SD \\
\hline Overall useful species & 300 & $26.5 \pm 7.0$ & 828 & $17.0 \pm 4.9$ & 312 & $14.4 \pm 5.3$ & 342 & $6.2 \pm 2.2$ & 268 & $12.5 \pm 4.8$ \\
\hline Overall use reports & & $75.92 \pm 29.4$ & & $47.19 \pm 17.6$ & & $41.55 \pm 20.2$ & & $14.37 \pm 6.0$ & & $38.95 \pm 16.5$ \\
\hline \multicolumn{11}{|l|}{ Comparison of means (categorical variables) } \\
\hline \multicolumn{11}{|l|}{ Gender } \\
\hline Male & 153 & $27.4 \pm 6.8^{\mathrm{a}}$ & 415 & $17.1 \pm 5.0^{\mathrm{a}}$ & 152 & $15.2 \pm 5.3^{\mathrm{a}}$ & 148 & $6.7 \pm 2.3^{\mathrm{a}}$ & 149 & $13.3 \pm 5.0^{\mathrm{a}}$ \\
\hline Female & 147 & $25.6 \pm 7.0^{\mathrm{b}}$ & 413 & $17.0 \pm 4.8^{\mathrm{a}}$ & 160 & $13.6 \pm 5.1^{\mathrm{b}}$ & 194 & $5.8 \pm 2.1^{b}$ & 119 & $11.4 \pm 4.2^{\mathrm{b}}$ \\
\hline \multicolumn{11}{|l|}{ Ethnicity } \\
\hline Indigenous & 299 & $26.5 \pm 7.0$ & 438 & $16.7 \pm 4.2^{\mathrm{b}}$ & 138 & $17.6 \pm 3.9^{\mathrm{a}}$ & 167 & $4.9 \pm 2.0^{\mathrm{b}}$ & 252 & $12.6 \pm 4.8^{\mathrm{a}}$ \\
\hline Mestizo & 1 & $18.0 *$ & 390 & $17.5 \pm 5.6^{\mathrm{a}}$ & 87 & $7.9 \pm 1.7^{\mathrm{c}}$ & 172 & $7.3 \pm 1.7^{\mathrm{a}}$ & 16 & $9.6 \pm 3.4^{\mathrm{b}}$ \\
\hline Afro-American & - & - & - & & 87 & $15.8 \pm 3.4^{\mathrm{b}}$ & 3 & $9.3 \pm 1.2^{*}$ & - & - \\
\hline \multicolumn{11}{|l|}{ Language spoken } \\
\hline Only native language & 15 & $25.6 \pm 6.0^{\mathrm{a}}$ & 19 & $17.6 \pm 4.2^{\mathrm{b}}$ & 12 & $20.2 \pm 1.6^{\mathrm{a}}$ & - & - & 4 & $15.5 \pm 6.2^{*}$ \\
\hline Only Spanish & 23 & $19.7 \pm 4.5^{\mathrm{b}}$ & 393 & $18.4 \pm 5.1^{\mathrm{a}}$ & 197 & $12.8 \pm 5.3^{\mathrm{b}}$ & 211 & $6.9 \pm 2.0^{\mathrm{a}}$ & 9 & $11.1 \pm 4.1^{*}$ \\
\hline Native language and Spanish & 262 & $27.1 \pm 6.9^{\mathrm{a}}$ & 416 & $15.7 \pm 4.4^{\mathrm{b}}$ & 103 & $16.8 \pm 4.0^{\mathrm{a}}$ & 131 & $5.0 \pm 2.0^{\mathrm{b}}$ & 255 & $12.5 \pm 4.7$ \\
\hline \multicolumn{11}{|l|}{ Migration status } \\
\hline Nonmigrant & 241 & $26.5 \pm 7.1^{\mathrm{a}}$ & 510 & $17.5 \pm 4.4^{\mathrm{b}}$ & 247 & $15.9 \pm 4.7^{\mathrm{a}}$ & 228 & $5.5 \pm 2.1^{\mathrm{b}}$ & 248 & $12.7 \pm 4.7^{\mathrm{a}}$ \\
\hline $\begin{array}{l}\text { Migrant from other ethnic group in the same } \\
\text { ecoregion }\end{array}$ & 58 & $26.5 \pm 6.4^{a}$ & 208 & $18.9 \pm 4.4^{\mathrm{a}}$ & 19 & $9.8 \pm 4.7^{\mathrm{b}}$ & 52 & $7.1 \pm 1.7^{\mathrm{a}}$ & 2 & $15.0 \pm 12.7^{*}$ \\
\hline Migrant from other ecoregion & 1 & $19.0^{*}$ & 110 & $11.5 \pm 4.0^{\mathrm{c}}$ & 46 & $8.4 \pm 2.0^{\mathrm{b}}$ & 62 & $7.8 \pm 1.7^{\mathrm{a}}$ & 18 & $9.4 \pm 3.2^{\mathrm{b}}$ \\
\hline \multicolumn{11}{|l|}{ Farm animal } \\
\hline No animals & 163 & $25.3 \pm 6.4^{\mathrm{b}}$ & 90 & $16.2 \pm 4.5^{\mathrm{b}}$ & 87 & $12.2 \pm 5.2^{\mathrm{b}}$ & 236 & $6.3 \pm 2.2^{\mathrm{a}}$ & 20 & $10.6 \pm 3.8^{\mathrm{a}}$ \\
\hline Subsistence livestock & 135 & $28.0 \pm 7.4^{\mathrm{a}}$ & 679 & $17.5 \pm 4.8^{\mathrm{a}}$ & 215 & $15.1 \pm 5.0^{\mathrm{a}}$ & 93 & $5.9 \pm 2.3^{\mathrm{a}}$ & 209 & $12.9 \pm 4.7^{\mathrm{a}}$ \\
\hline Commercial livestock & 2 & $21.5 \pm 3.5^{*}$ & 59 & $12.6 \pm 3.6^{\circ}$ & 10 & $18.2 \pm 4.2^{\mathrm{a}}$ & 13 & $6.0 \pm 1.6^{\mathrm{a}}$ & 39 & $11.1 \pm 5.0^{\mathrm{a}}$ \\
\hline \multicolumn{11}{|l|}{ Tools } \\
\hline Low cost & 212 & $27.3 \pm 7.2^{\mathrm{a}}$ & 91 & $17.9 \pm 5.1^{\mathrm{a}}$ & 299 & $14.3 \pm 5.3$ & 339 & $6.2 \pm 2.2$ & 81 & $12.1 \pm 4.8^{\mathrm{a}}$ \\
\hline Average cost & 75 & $24.7 \pm 5.9^{\mathrm{b}}$ & 557 & $17.6 \pm 4.8^{\mathrm{a}}$ & 9 & $17.8 \pm 4.8^{*}$ & 1 & $8.0^{*}$ & 128 & $13.5 \pm 5.2^{\mathrm{a}}$ \\
\hline High cost & 13 & $24.5 \pm 6.0^{\mathrm{b}}$ & 180 & $14.9 \pm 4.4^{\mathrm{b}}$ & 4 & $13.5 \pm 1.7^{*}$ & 2 & $8.0^{*}$ & 59 & $10.8 \pm 2.6^{\mathrm{a}}$ \\
\hline \multicolumn{11}{|l|}{ Transport } \\
\hline No transport & 109 & $25.8 \pm 7.0^{\mathrm{a}}$ & 236 & $17.0 \pm 5.0^{\mathrm{a}}$ & 185 & $12.0 \pm 4.7^{\mathrm{c}}$ & 284 & $6.4 \pm 2.1^{\mathrm{a}}$ & 210 & $13.1 \pm 5.0^{\mathrm{a}}$ \\
\hline No fuel consumption & 146 & $27.5 \pm 6.6^{\mathrm{a}}$ & 295 & $16.7 \pm 4.8^{\mathrm{a}}$ & 100 & $18.8 \pm 3.3^{\mathrm{a}}$ & 25 & $4.0 \pm 1.8^{\mathrm{b}}$ & 51 & $9.7 \pm 1.8^{\mathrm{b}}$ \\
\hline Low fuel consumption & 24 & $26.3 \pm 8.4^{\mathrm{a}}$ & 272 & $17.4 \pm 4.7^{\mathrm{a}}$ & 17 & $14.6 \pm 5.0^{\mathrm{b}}$ & 14 & $4.1 \pm 2.2^{\mathrm{b}}$ & 2 & $14.0 \pm 11.3^{*}$ \\
\hline High fuel consumption & 21 & $23.2 \pm 6.7^{b}$ & 25 & $16.9 \pm 6.4^{\mathrm{a}}$ & 10 & $14.2 \pm 2.3^{b}$ & 19 & $6.8 \pm 1.2^{\mathrm{a}}$ & 5 & $12.6 \pm 5.4^{*}$ \\
\hline \multicolumn{11}{|l|}{ House construction materials } \\
\hline Local plant materials $\geq 50 \%$ & 122 & $29.0 \pm 5.5^{\mathrm{a}}$ & 634 & $17.5 \pm 4.7^{\mathrm{a}}$ & 25 & $18.0 \pm 4.5^{\mathrm{a}}$ & - & - & 71 & $10.1 \pm 2.4^{\mathrm{b}}$ \\
\hline Mixed material $\geq 50 \%$ & 9 & $30.3 \pm 4.1^{*}$ & 18 & $13.4 \pm 5.0^{\mathrm{b}}$ & 210 & $12.1 \pm 4.5^{\mathrm{b}}$ & 306 & $6.0 \pm 2.2^{b}$ & 13 & $13.5 \pm 5.1^{\mathrm{a}}$ \\
\hline Foreign commercial materials $\geq 50 \%$ & 169 & $24.5 \pm 7.4^{\mathrm{b}}$ & 176 & $15.7 \pm 5.3^{\mathrm{b}}$ & 77 & $19.6 \pm 2.5^{\mathrm{a}}$ & 36 & $7.4 \pm 2.1^{\mathrm{a}}$ & 184 & $13.3 \pm 5.1^{\mathrm{a}}$ \\
\hline Age & & 0.36 & & 0.09 & & 0.11 & & 0.12 & & 0.17 \\
\hline Size of family (number of children) & & 0.12 & & 0.22 & & 0.32 & & 0.04 & & -0.07 \\
\hline Education & & -0.08 & & 0.01 & & -0.51 & & -0.05 & & -0.23 \\
\hline Time in residence (years) & & 0.41 & & 0.2 & & -0.05 & & -0.14 & & 0.36 \\
\hline Farms size (ha) & & -0.17 & & -0.04 & & -0.09 & & 0.06 & & -0.06 \\
\hline House size $\left(\mathbf{m}^{2}\right)$ & & -0.04 & & 0.002 & & -0.27 & & 0.01 & & 0.47 \\
\hline
\end{tabular}

the other two subregions. Afro-Americans were surveyed only in the Choco and were the group that knew most after the indigenous population. We did not evaluate ethnicity among the locations of the northern Amazon because all informants were indigenous. The relationship between family size (expressed as the number of children) and knowledge presented a positive trend in all cases. The effect was lowest in the northern Andes $(r=0.04)$ and highest in the Chocó $(r=0.32)$. In contrast, in the southern Andes, the effect was slightly negative $(r=-0.07)$. Concerning education, we found a negative relationship in all subregions, indicating that people had less knowledge about useful palms the longer they had received formal education, except in the southern Amazon. In the northern Amazon, southern Andes, and Chocó, people who spoke exclusively the local language or who also spoke Spanish had greater knowledge than people who spoke only Spanish. In contrast, we found the opposite pattern in the southern Amazon and northern Andes. People who immigrated from a different ecoregion to where they are living now had less knowledge, except in the northern Andes, where their knowledge was greater. The relationship between the time of residence in the community and knowledge was positive, indicating that people living longer in a place had a greater knowledge about useful palms in three of the five subregions evaluated, with the degree declining from the northern Amazon to the southern Amazon and southern Andes. For locations in the northern Andes and the Chocó, the relationship was negative but with a very low slope.

In the northern and southern Amazon, people with a low purchasing power had a greater knowledge (Table 3). Specifically, people who possessed only subsistence-oriented animals, basic tools, and small areas of cultivation, and who used local materials to build mainly small houses had greater knowledge. The transportation system did not affect knowledge differences. 
Table 4. Mixed-model effect of the number of known useful palms species and coefficients of the 14 socioeconomic factors evaluated in the five subregions of northwestern South America. Levels of significance: ${ }^{*} p<0.05 ; * *<0.01$. ne: not evaluated; nd: no data. Reference categories are (1) Men; (2) Indigenous; (3) Only native language spoken; (4) Nonmigrant; (5) Nonfarm animals; (6) Low cost tools; (7) No transport; (8) House construction with $\geq 50 \%$ of local plant materials.

\begin{tabular}{|c|c|c|c|c|c|}
\hline & $\begin{array}{l}\text { Northern } \\
\text { Amazon }\end{array}$ & $\begin{array}{l}\text { Southern } \\
\text { Amazon }\end{array}$ & Chocó & $\begin{array}{l}\text { Northern } \\
\text { Andes }\end{array}$ & Southern Andes \\
\hline Intercept $\left(\gamma_{00}\right)$ & $21.991 * *$ & $13.677 * *$ & $15.52 * *$ & $4.948^{* *}$ & $12.318^{* *}$ \\
\hline \multicolumn{6}{|l|}{ Socieconomic factors } \\
\hline Women $^{(1)}$ & $-2.159 * *$ & $-0.534 * *$ & $-1.175 * *$ & $-0.513^{* *}$ & $-1.407 * *$ \\
\hline Age & $0.118 * *$ & $0.037 * *$ & $0.068 * *$ & 0.014 & -0.005 \\
\hline Mestizo $^{(2)}$ & nd & 0.128 & -7.188 & 1.408 & -0.234 \\
\hline Afro-American ${ }^{(2)}$ & nd & nd & -3.617 & $2.940^{*}$ & - \\
\hline Size of family & 0.067 & $0.086^{*}$ & ne & ne & ne \\
\hline Education & 0.002 & 0.052 & $-0.083^{*}$ & -0.006 & 0.001 \\
\hline Only Spanish spoken ${ }^{(3)}$ & 0.125 & -0.566 & -0.089 & 0.001 & ne \\
\hline Native language and Spanish spoken ${ }^{(3)}$ & 0.552 & -0.118 & -0.868 & 0.545 & ne \\
\hline Migrant from other ethnic group in the same ecoregion ${ }^{(4)}$ & 0.591 & 0.195 & -0.744 & 0.048 & 0.985 \\
\hline Migrant from other ecoregion ${ }^{(4)}$ & $-12.211 *$ & $-1.502 * *$ & -0.77 & 0.65 & -2.495 \\
\hline Time in residence & 0.024 & 0.01 & -0.003 & -0.003 & 0.011 \\
\hline Subsistence livestock $^{(5)}$ & 0.782 & $0.731^{*}$ & -0.118 & ne & ne \\
\hline Commercial livestock $^{(5)}$ & -0.166 & 0.356 & $1.813^{*}$ & ne & ne \\
\hline Farm size & 0.348 & ne & -0.003 & ne & ne \\
\hline Average cost tools ${ }^{(6)}$ & -0.236 & $1.210^{* *}$ & ne & ne & ne \\
\hline High cost tools $^{(6)}$ & -0.448 & $1.285^{* *}$ & ne & ne & ne \\
\hline No fuel consumption transport ${ }^{(7)}$ & $-1.266^{*}$ & ne & 0.118 & -0.360 & -0.138 \\
\hline Low fuel consumption transport ${ }^{(7)}$ & 0.009 & ne & 1.075 & 0.005 & 1.534 \\
\hline High fuel consumption transport ${ }^{(7)}$ & 0.455 & ne & -0.235 & -0.177 & -0.085 \\
\hline House size & ne & ne & 0.004 & ne & $0.013 *$ \\
\hline House construction with $\geq 50 \%$ of mixed material ${ }^{(8)}$ & 0.625 & -0.743 & -0.072 & 0.000 & 0.532 \\
\hline $\begin{array}{l}\text { House construction with } \geq 50 \% \text { of foreign commercial } \\
\text { materials }\end{array}$ & $-2.142 * *$ & 0.218 & 0.057 & 0.174 & 0.005 \\
\hline Locality standard deviation $\left(\sigma_{L}\right)$ & 5.276 & 4.113 & 3.599 & 1.118 & 4.037 \\
\hline Interviewed residuals $\left(e_{i j}\right)$ & 4.041 & 2.599 & 2.131 & 1.628 & 2.863 \\
\hline
\end{tabular}

Within the Chocó, knowledge was positively related to animal husbandry for subsistence or markets, to basic tools, to small areas of crops (although the slope was small, $r=0.27$ ), and to transport that did not use fuel. Knowledge was not related to the use of local (cheaper) or external (more expensive) construction materials in homes. In the Andes, we found two different patterns: in the northern Andes, animal husbandry and possession of tools determined differences in knowledge. Size of cultivated land showed a very low correlation $(r=0.06)$. A greater knowledge corresponded to people either lacking transportation or having transportation with high fuel consumption (more expensive), and to primarily external materials (more expensive) for construction of homes, which were larger. In the southern Andes, only the absence of transportation and larger homes were associated with greater TK.

\section{Multivariate analysis and palm-use knowledge}

We found that two to six socioeconomic factors had a significant association with knowledge of the informants in the five subregions evaluated (Table 4). Of these, gender had a significant association in all five subregions. Similar to the descriptive analyses, in all subregions, men had more knowledge than women, although the difference was just slightly more than two species. Differences were greatest among locations of the northern Amazon (2.1 species less), followed by the southern Andes (1.4 species less).
Age had a positive significant association only in the lowlands (Amazon and Chocó) (Table 4). However, the increase in knowledge with age was very low ( $0.1-0.02$ species per year). This increase was greater in the northern Amazon than in the southern Amazon. Ethnicity had a significant association with knowledge only in the northern Andes, and Afro-Americans had a greater knowledge than the mestizo and indigenous population (approximately 3 species more). Family size had a significant positive association only in the southern Amazon (0.1 species per additional family member). Education had a significant but negative association only in the Chocó $(0.1$ species less per year of education). The migration status of people had an effect only in the Amazon. In both northern and southern Amazon subregions, migrants knew fewer palm species than nonmigrants. The difference was greatest in the northern Amazon, where migrants knew up to 12 species less. No significant association was found in any of the five subregions evaluated for language spoken or residence time.

Regarding the factors that measured the purchasing power of local inhabitants, we found that between one and two factors had a significant association with knowledge of the informants in the five subregions, except in the northern Andes (Table 4). In the northern Amazon, we found a significant association with means of transport. People with basic means of transport, with no fuel consumption, knew fewer species ( 1.3 species). In addition, people 
who used mainly external materials (often acquired in trade centers) to build their house knew fewer species ( 2.1 species) than those who used only local material or a mixture of local and external materials. In the southern Amazon, animal tenure had a positive significant association with knowledge, with people who raised animals for subsistence reporting more species $(0.7$ more species) than people who did not keep animals or who raised livestock for commercial purposes. People who had high-cost tools (e.g., tractors, chainsaws, sprayers, water pumps) had more knowledge (1.3 species more) than people who had tools of average cost (e.g., fishing nets, trucks, shotguns/rifles, plows, seeders) or tools that were common to most people (e.g., machetes, axes, bows and arrows, fishhooks, traditional farming tools) and other basic tools (low cost). In the Chocó, we found that only livestock keeping had a significant association with knowledge, with people who raised animals for commercial purposes having more knowledge than people who did not have any animals or were breeding them only for subsistence ( 1.8 more species). House size was the only factor that had a significant association with knowledge in the southern Andes, with people who had larger houses reporting more species $\left(0.01\right.$ species more per $1 \mathrm{~m}^{2}$ increase in house surface).

Palm-use knowledge by use categories and socioeconomic factors The distribution of palm use in the 10 use categories showed similar patterns in the five subregions (Fig. 2). The six categories with the highest use values were Human food, Construction, Utensils and tools, Cultural, Medicinal and veterinary, and Other uses. In the northern Andes, these two last categories were irrelevant.

The multivariate model applied to each of the use categories in each of the five subregions showed that between one and seven of the 14 socioeconomic factors had a significant association with the palm-use knowledge of the informants (Table 5). However, none of the factors had a common association with all use categories in the five subregions. Gender showed a significant association primarily in the southern Andes, which influenced six use categories (of the eight evaluated). In all cases, men's knowledge was greater than women's, especially regarding Construction, Utensils and tools, and Human food. Age had a significant positive association with palm species knowledge, and most use categories in the lowlands (Amazon and Chocó) showed high significance levels. The association with use categories was similar between localities of the Amazon. In contrast to the Amazon, in the Chocó, we found that Construction, Medicinal and veterinary, and Utensils and tools did not show a significant association. Ethnicity had a significant association mainly in the northern Andes, where Afro-Americans had a greater knowledge about Medicinal and veterinary species but less about Utensils and tools, and mestizos had more knowledge about Human food and Environmental use. In the Chocó, Afro-Americans had a greater knowledge about the Environmental use of palms but less knowledge about the use for Human food, and the mestizos had less knowledge than the indigenous about Cultural use and Human food. Family size had a significant association mainly in the southern Amazon, where the association was positive regarding Human food, Utensils and tools, and Other uses. Education had a significant association in only three subregions. In the southern Amazon, it had a positive association with
Fig. 2. Average number of use reports (dark grey bars) and useful species (light grey bars) in the five subregions in northwestern South America reported by 2050 informants in 10 use categories: Human food (HmFd); Construction (Const); Utensils and tools (Utens); Cultural (Cult); Other uses (Other); Medicinal and veterinary (Medic); Fuel; Animal food (AnFd); Environmental (Envi); Toxic.
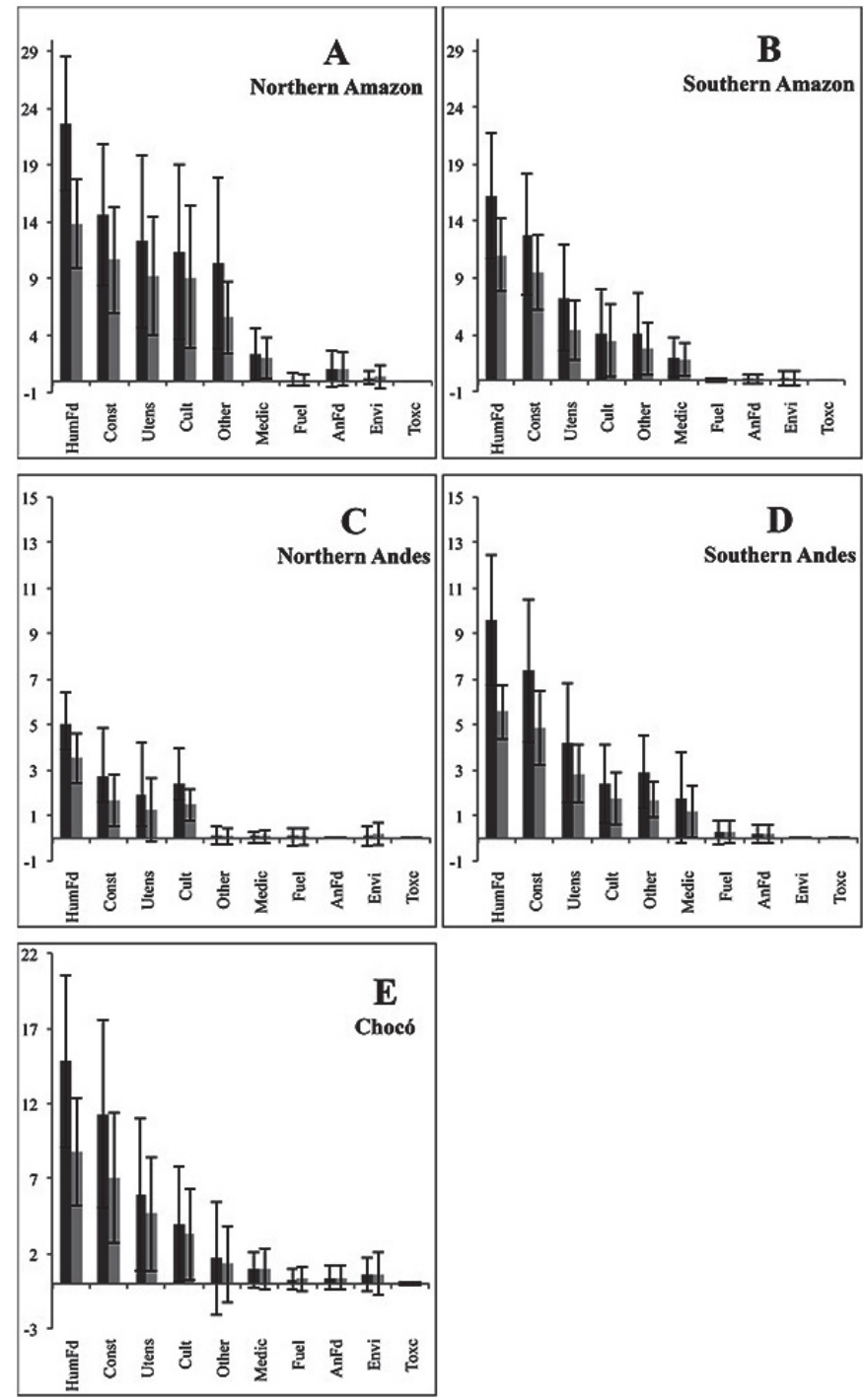

Cultural use, Medicinal and veterinary, and Utensils and tools. In the northern Andes, the positive association affected only Cultural use; in the southern Andes, the positive association affected the use for Animal food. The language spoken had a significant association with Medicinal and veterinary knowledge in the southern Amazon, where people who spoke Spanish and the local language had better knowledge than people who spoke only Spanish or only their local language. The same pattern was found in the northern Andes for Human food, while an opposite pattern was found for Fuel. In the Chocó, people who spoke Spanish had greater knowledge regarding 
Table 5. Mixed-model effect of the number of known useful palm species in all use categories and the coefficients of the 14 socieoeconomic factors with significant association in the five subregions in northwestern South America. Levels of significance: ${ }^{*} p<0.05 ; * * p<0.01$. Reference categories are (1) Men; (2) Indigenous; (3) Only native language spoken; (4) Nonmigrant; (5) Nonfarm animals; (6) Lowcost tools; (7) No transport; (8) House construction with $\geq 50 \%$ of local plant materials. Use categories: Animal food (AnFd); Construction (Const); Cultural (Cult); Environmental (Envir); Fuel; Human food (HmFd); Medicinal and veterinary (MedVet); Toxic; Utensils and tools (Utens); Other uses (Other). (-): no data.

\begin{tabular}{|c|c|c|c|c|c|c|c|c|c|c|}
\hline & ANFD & CONST & CULT & ENVIR & FUEL & HMFD & $\begin{array}{l}\text { MEDV- } \\
\text { ET }\end{array}$ & TOXIC & UTENS & OTHER \\
\hline \multicolumn{11}{|l|}{ Northern Amazon } \\
\hline Intercept $\left(\gamma_{00}\right)$ & 0.958 & $7.518^{* *}$ & $9.278 * *$ & 0.155 & 0.198 & $13.229 * *$ & 1.404 & - & $7.523^{* *}$ & $4.299 *$ \\
\hline \multicolumn{11}{|l|}{ Socioeconomic factors } \\
\hline Women $^{(1)}$ & $-0.388 * *$ & & & & & & & - & & \\
\hline Age & & $0.09 * *$ & & & & $0.067 * *$ & $0.023^{*}$ & - & $0.101 * *$ & $0.047 * *$ \\
\hline Size of family & & & & & & & & - & & $-0.102 *$ \\
\hline Subsistence livestock $^{(5)}$ & $0.359 *$ & & & & & & & - & & \\
\hline Farm size & $-0.319 * *$ & & & & & & $-0.332 *$ & - & $-1.235^{*}$ & \\
\hline Average cost tools ${ }^{(6)}$ & & & & $0.294^{*}$ & & & & - & & \\
\hline No fuel consumption transport ${ }^{(7)}$ & & & & & $-0.175^{*}$ & & & - & & \\
\hline Low fuel consumption transport ${ }^{(7)}$ & & & & & $-0.259 *$ & & & - & & \\
\hline High fuel consumption transport ${ }^{(7)}$ & & $-2.052 *$ & & & & & & - & & \\
\hline $\begin{array}{l}\text { House construction with } \geq 50 \% \text { of mixed } \\
\text { material }^{(8)}\end{array}$ & & & $-4.481 * *$ & & & & & - & & \\
\hline $\begin{array}{l}\text { House construction with } \geq 50 \% \text { of foreign } \\
\text { commercial materials }^{(8)}\end{array}$ & & & & & & $-1.30 * *$ & & - & & \\
\hline Locality standard deviation $\left(\sigma_{L}\right)$ & 1.211 & 3.092 & 5.864 & 0.501 & 0.146 & 2.703 & 1.211 & - & 2.419 & 2.961 \\
\hline Interviewed residuals $\left(e_{i j}\right)$ & 1.073 & 3.71 & 3.534 & 0.93 & 0.506 & 2.728 & 1.333 & - & 4.469 & 2.028 \\
\hline \multicolumn{11}{|l|}{ Southern Amazon } \\
\hline Intercept $\left(\gamma_{00}\right)$ & -0.051 & $6.574 * *$ & 0.186 & 0.157 & -0.006 & $9.577^{* *}$ & 0.294 & - & $2.266^{* *}$ & $1.862 *$ \\
\hline \multicolumn{11}{|l|}{ Socioeconomic factors } \\
\hline Women $^{(1)}$ & & $-0.526^{* *}$ & 0.015 & & & $-0.325^{*}$ & & - & & \\
\hline Age & & $0.035 * *$ & $0.016^{*}$ & & & $0.018 * *$ & $0.01 * *$ & - & $0.024 * *$ & \\
\hline Mestizo $^{(2)}$ & & & & & $-0.096 * *$ & & & - & & \\
\hline Size of family & & & & & & $0.105^{* *}$ & & - & $0.054 *$ & $0.040^{*}$ \\
\hline Education & & & $0.084 * *$ & & & & $0.042^{* *}$ & - & $0.052 *$ & \\
\hline Native language and Spanish spoken ${ }^{(3)}$ & & & & & & & $0.693 * *$ & - & & \\
\hline Migrant from other ecoregion ${ }^{(4)}$ & & $-0.729 *$ & $-0.651 *$ & & $0.062 * *$ & $-1.05 * *$ & & - & $-1.069 * *$ & -0.119 \\
\hline Subsistence livestock ${ }^{(5)}$ & & & $1.001 * *$ & & & & & - & $0.540^{*}$ & $0.508 * *$ \\
\hline Commercial livestock $^{(5)}$ & & & $1.25^{* *}$ & $0.212^{* *}$ & & & & - & & \\
\hline Average cost tools ${ }^{(6)}$ & & $0.720^{*}$ & $1.190^{* *}$ & & & & & - & $0.995 * *$ & $0.357^{*}$ \\
\hline High cost tools $^{(6)}$ & & $0.836^{*}$ & $1.245^{* *}$ & & & & & - & $0.804 * *$ & \\
\hline $\begin{array}{l}\text { House construction with } \geq 50 \% \text { of foreign } \\
\text { commercial materials }^{(8)}\end{array}$ & & $0.422 *$ & $0.633 * *$ & & & $0.55^{* *}$ & & - & $0.459 *$ & $0.256^{*}$ \\
\hline Locality standard deviation $\left(\sigma_{L}\right)$ & 0.175 & 2.541 & 2.502 & 0.526 & 0.038 & 2.488 & 1.036 & - & 1.654 & 2.004 \\
\hline $\begin{array}{l}\text { Interviewed residuals }\left(e_{i j}\right) \\
\text { Chocó }\end{array}$ & 0.383 & 2.113 & 1.874 & 0.416 & 0.143 & 1.871 & 1.035 & - & 1.899 & 1.288 \\
\hline Intercept $\left(\gamma_{00}\right)$ & 0.385 & $7.754^{* *}$ & $5.643 * *$ & 0.538 & $1.011^{* *}$ & $8.622 * *$ & 0.964 & 0.061 & $5.848 * *$ & 2.475 \\
\hline \multicolumn{11}{|l|}{ Socioeconomic factors } \\
\hline Women $^{(1)}$ & & & & & $-0.231 * *$ & & & & & \\
\hline Age & $0.006^{*}$ & & $0.018 *$ & & & $0.023^{*}$ & & & & $0.017 * *$ \\
\hline Mestizo $^{(2)}$ & & & & & & $-5.33 * *$ & & & & \\
\hline Afro-American ${ }^{(2)}$ & & & & $2.037^{*}$ & & $-3.054^{*}$ & & & & \\
\hline Only Spanish spoken ${ }^{(3)}$ & & & & & & $1.778 *$ & & & & \\
\hline Subsistence livestock ${ }^{(5)}$ & & & & & & & & & $0.744^{*}$ & \\
\hline Commercial livestock $^{(5)}$ & $1.436^{* *}$ & $2.346^{*}$ & & $1.214^{* *}$ & & $1.983^{*}$ & $1.449 * *$ & & $2.919 * *$ & \\
\hline No fuel consumption transport ${ }^{(7)}$ & $0.324^{*}$ & & & & & & & & & \\
\hline High fuel consumption transport ${ }^{(7)}$ & & & & $0.984^{*}$ & & & $0.931^{*}$ & & & \\
\hline $\begin{array}{l}\text { House construction with } \geq 50 \% \text { of mixed } \\
\text { material }^{(8)}\end{array}$ & & $-2.156^{*}$ & $-1.623^{*}$ & $-1.171 * *$ & $-0.493^{*}$ & & $-1.079 * *$ & $-0.135^{*}$ & $-2.295 * *$ & \\
\hline $\begin{array}{l}\text { House construction with } \geq 50 \% \text { of foreign } \\
\text { commercial materials }^{(8)}\end{array}$ & & & $-1.465 * *$ & & $-0.487^{*}$ & & & & $-1.480 *$ & \\
\hline
\end{tabular}




\begin{tabular}{|c|c|c|c|c|c|c|c|c|c|c|}
\hline Locality standard deviation $\left(\sigma_{L}\right)$ & 0.229 & 2.706 & 1.681 & 0.768 & 0.119 & 1.022 & 0.465 & 0.063 & 2.143 & 2.964 \\
\hline Interviewed residuals $\left(e_{i j}\right)$ & 0.693 & 2.652 & 2.147 & 1.268 & 0.742 & 2.25 & 1.25 & 0.11 & 2.668 & 1.384 \\
\hline Intercept $\left(\gamma_{00}\right)$ & - & $1.63^{* *}$ & $1.159 * *$ & 0.06 & $0.364 * *$ & $3.095^{* *}$ & 0.18 & - & $1.84 * *$ & -0.01 \\
\hline Socioeconomic factors & & & & & & & & & & \\
\hline Women $^{(1)}$ & - & & & & $-0.105^{*}$ & & & - & & \\
\hline Mestizo $^{(2)}$ & - & & & $0.215^{*}$ & $-0.363 * *$ & $1.295^{* *}$ & & - & & \\
\hline Afro-American ${ }^{(2)}$ & - & & & & & & $0.555^{* *}$ & - & $-1.573^{*}$ & \\
\hline Education & - & & $0.019^{*}$ & & & & & - & & \\
\hline Native language and Spanish spoken ${ }^{(3)}$ & - & & & & $-0.231 * *$ & $0.388^{*}$ & & - & & \\
\hline $\begin{array}{l}\text { Migrant from other ethnic group in the same } \\
\text { ecoregion }{ }^{(4)}\end{array}$ & - & & $0.34^{*}$ & $0.271^{*}$ & & & & - & -0.088 & \\
\hline Locality standard deviation $\left(\sigma_{L}\right)$ & - & 0.155 & 0.269 & 0.001 & 0.093 & 0.464 & 0.062 & - & 0.729 & 0.092 \\
\hline Interviewed residuals $\left(e_{i j}\right)$ & - & 1.092 & 0.682 & 0.469 & 0.386 & 0.799 & 0.280 & - & 0.969 & 0.352 \\
\hline Southern Andes & & & & & & & & & & \\
\hline $\begin{array}{l}\text { Intercept }\left(\gamma_{00}\right) \\
\text { Socioeconomic factors }\end{array}$ & -0.137 & $4.372^{* *}$ & $1.398 * *$ & - & $0.387^{*}$ & $5.458^{* *}$ & $1.757^{* *}$ & - & $2.855^{* *}$ & $2.179^{* *}$ \\
\hline Women $^{(1)}$ & & $-0.85 * *$ & $-0.425 * *$ & - & & $-0.436^{* *}$ & $-0.386^{* *}$ & - & $-0.482 * *$ & $-0.363^{* *}$ \\
\hline Age & & & & - & & & & - & & $-0.011^{*}$ \\
\hline Education & $0.034^{* *}$ & & & - & & & & - & & \\
\hline $\begin{array}{l}\text { Migrant from other ethnic group in the same } \\
\text { ecoregion }^{(4)}\end{array}$ & & & $1.682^{*}$ & - & & & & - & & \\
\hline Migrant from other ecoregion ${ }^{(4)}$ & $-0.492 *$ & & & - & & & & - & & \\
\hline High fuel consumption transport ${ }^{(7)}$ & & & & - & & & $-1.271^{* *}$ & - & & \\
\hline House size & & $0.009 * *$ & $0.009 * *$ & - & & & & - & & \\
\hline $\begin{array}{l}\text { House construction with } \geq 50 \% \text { of mixed } \\
\text { material }^{(8)}\end{array}$ & $-0.218^{*}$ & & & - & & & & - & & \\
\hline $\begin{array}{l}\text { House construction with } \geq 50 \% \text { of foreign } \\
\text { commercial materials }{ }^{(8)}\end{array}$ & & & $0.383^{*}$ & - & & & & - & & \\
\hline Locality standard deviation $\left(\sigma_{L}\right)$ & 0.346 & 0.97 & 0.641 & - & 0.109 & 0.437 & 0.674 & - & 0.659 & 0.001 \\
\hline Interviewed residuals $\left(e_{i, j}\right)$ & 0.315 & 1.441 & 1.067 & - & 0.497 & 1.141 & 1.043 & - & 1.214 & 0.759 \\
\hline
\end{tabular}

the use for Human food than people who spoke only their local language.

Migration status had a significant association with knowledge in the southern Amazon, where people who had migrated from a different ecoregion knew fewer palm species for Construction, Cultural use, Human food, and Utensils and tools than did nonmigrants (Table 5). In the Andes, people who had migrated from the same ecoregion had more TK about Cultural uses than people who had not migrated. The same pattern was found for Environmental uses in the northern Andes. None of the five subregions showed a significant association with time of residence in the community for any of the use categories.

Many of the factors that measured the purchasing power of local inhabitants showed an association with TK in the lowlands (Amazon and Chocó) (Table 5). In the northern Amazon, people who raised animals for subsistence knew more Animal food uses than people who did not breed animals. The same pattern was found in the southern Amazon for Cultural use, Utensils and tools, and for Other uses, and in the Chocó for Utensils and tools. A different pattern was found in the southern Amazon, where people who raised animals for commercial purposes knew more Cultural and Environmental uses than people who raised animals only for subsistence. The same pattern was found in the Chocó for all uses except Cultural, Fuel, Toxic, and Other uses. Farm size had a significant association with TK only in the northern Amazon, where people who had larger fields knew less Animal food, Medicinal and veterinary, and Utensils and tools uses. The association between the possession of tools and TK was evaluated only in the Amazon ecoregion, and it was significant in the southern Amazon, where people who did not have any tools were less knowledgeable about Construction, Cultural use, Utensils and tools, and Other uses. The possession of a means of transport had a significant association only in the northern Amazon, where knowledge in Construction was lower among people who had transport with higher fuel consumption, while in the Chocó, knowledge about Environmental and Medicinal and veterinary uses of palms was lower among respondents who had transport with low fuel consumption. House size, evaluated in only two subregions, had a positive association in the northern Andes, especially with Construction and Cultural use, indicating that people who had bigger houses generally were more knowledgeable. The material used in the construction of houses mainly had an association with palm knowledge in the lowlands. In the Chocó, people who used mainly local material for their houses knew more regarding all categories than people who used mixed or external material. In the northern Amazon, people who had their houses built with external materials knew less about Human food than those who had built their homes using mixed material. In the southern Amazon, people who used primarily external material had a greater knowledge regarding Construction, Cultural use, Human food, and Utensils and tools than those who used mixed material in their home construction.

\section{DISCUSSION}

Our analyses highlight the strong association between socioeconomic factors and TK about palms across ecoregions in northwestern South America, and the existence of distinct 
patterns in all subregions. The influence of socioeconomic factors on TK varied when overall palm-use knowledge or knowledge in the different use categories were considered.

In most subregions, men knew more useful palm species than women, which could be a result of the division of responsibilities, duties, and experience at the intra- and interhousehold level or even the community level due to their greater participation in activities such as hunting, clearing fields, building houses, and making tools (Hanazaki et al. 2000, Byg and Balslev 2004). In the Amazon, this might be explained by the fact that the harvest of palms, to a large extent, requires great physical strength, and is done by men, although women might do the final processing. The significant differences found in the Andes can be explained by the fact that men tend to work outside their villages and travel much more than women, which gives them more opportunities to learn new uses for palm species they already know. With the exception of the southern Andes, our study did not find significant differences based on gender in use categories such as Medicinal and veterinary or Cultural, whereas earlier studies reported women had a greater knowledge of these categories (Figueiredo et al. 1993, Stagegaard et al. 2002).

Age was associated with differences in TK in the lowlands but not in the Andes. Although we did not find a tendency for the influence of age in relation to the use categories, the low slope with respect to the relationship between age and knowledge in the localities of the lowlands suggests that older people are not "experts" with a much greater knowledge than younger people. This suggests an ongoing process of transmission and in situ acquisition of TK through contact with their environment when covering the necessities that arise over their lives (Phillips and Gentry 1993, Zarger 2002, Paniagua Zambrana et al. 2007, Godoy et al. 2009).

Our results related to ethnicity indicate that in some regions the indigenous population has more knowledge in some categories, especially those closely linked with cultural use of forest resources, like Medicinal and veterinary and Human food, as reported in other studies (Ladio 2001, Campos and Ehringhaus 2003, Balslev et al. 2010). In other cases, however, the TK of mestizos was equal to, or even greater than, that of the indigenous population. This has been interpreted in other studies as an effect of mestizos' ample experience with external resources, which may motivate an interest to learn about resources available in their nearby environment (Byg et al. 2007, Paniagua Zambrana et al. 2007). However, this could also be influenced by the greater access of mestizo communities to markets, which could encourage them to learn about palm species that can provide additional income. On the other hand, our finding that the TK of Afro-Americans was almost similar to that of the indigenous population could reflect the long history of contact that has favored knowledge exchange (Caballero 1995). Most of our study communities in the Chocó have much better market access than those in the Amazon, resulting in a reduced dependence on palm resources, which could have led to lower TK levels in the indigenous population of the former region.

The influence of family size on knowledge has been linked to the ability to successfully meet the needs of the household, mainly related to food and health. Although in general terms, the median number of children per family is not very high and does not differ between the subregions (between 3.7 and 4.7) (Appendix 2), family size had a positive association with TK only in the southern Amazon, and only regarding knowledge about Human food and Other uses. This association could be related to the influence of other factors such as education, which was positive in these localities, or to ethnicity because these uses could be closely related to traditional culture and its appreciation by the local population.

The Chocó was the only region where formal education had a significant negative association with palm-use knowledge. A negative association of education with TK has been reported because children and adolescents are removed from their natural, cultural, and physical environment to obtain a better formal education, which in turn limits the opportunity to learn about and participate in activities related to the transmission of TK from their elders (Somnasang and Moreno-Black 2000, Zarger 2002, Ladio and Lozada 2004). An opposite effect was observed in the localities of the southern Amazon, where the average number of years at school was lowest. Such effect was most closely linked with cultural use of forest resources, and could reflect the inclination of people with a formal education to place a greater value on TK and strive harder to acquire it (Zent 1999), thus helping to generate environmental awareness (Godoy and Contreras 2001, Heckler 2002).

The patterns we found in relation to the language spoken and its association with knowledge contradict other findings that associate increasing bilingualism with lower ethnobotanical knowledge (Zent 2001). However, this pattern could also be related to the stages of the learning process. During the early stages of life, learning is often strongly linked to the local language of the community. In contrast, at later stages, learning is influenced by formal education, which frequently limits the use of native languages. From adolescence to adulthood, learning involves a strong acquisition of practical skills that are necessary for establishing a new family (Ohmagari and Berkes 1997, Hunn 2002, Reyes-García et al. 2007). At all these stages, language provides the mechanism for socialization and intergenerational and intercultural knowledge transfer, favoring the acquisition of new knowledge that could be useful, such as use for Human food, as shown in our study.

The association between migration status and knowledge was significant only in the Amazon, which could reflect a longer tradition of palm use in this ecoregion (Campos and Ehringhaus 2003) but also a greater reliance on oral traditions for cultural transmission. Additionally, migration of informants into communities of a different ethnicity in the same ecoregion could give them access to additional knowledge through new worldviews and different cultural uses of palms. The high values found in the northern Amazon with relation to this factor, especially regarding migrants from other ecoregions, could be considered an artifact due to the small sample size of this group.

In our study, wealth was measured primarily as agricultural and livestock assets, and therefore reflects the different productive practices people engage in. The extraction and use of natural resources such as plants is an integral part of livelihood strategies, and socioeconomic tradeoffs regarding investment in external agricultural practices, animal husbandry, tools, capital, and labor influence the use of natural resources and the interest in maintaining TK (Coomes 1996, Wiersum 1997, Takasaki et al. 
2001). However, the different practices and productive activities of households could also be related to factors such as family history, availability of labor and capital, and past experiences (Scatena et al. 1996, Coomes and Barham 1997). A loss of interest in TK of plants and other natural resources could also be due to the availability of alternative industrial products that people can access due to the availability of alternative opportunities, such as wage labor, trade-oriented agriculture, or migration to urban centers (Benz et al. 2000, Ladio 2001, Ladio and Lozada 2001). In general terms, our results show that the association of wealth with knowledge was not very strong. In the northern Amazon, members of the less wealthy families knew a greater number of species of useful palms for categories like Construction, Human food, and Cultural use. In agreement with past studies, we found that people with less access to purchased goods had a better knowledge of useful species (Arnold and Ruiz Pérez 2001), although this was probably influenced by the reduced access of the communities to commercial centers (Byg and Balslev 2001, Byg et al. 2007). We encountered the opposite effect in the southern Amazon, the Chocó, and the southern Andes, where people who had better access to markets knew more about Construction, Utensils and tools, Cultural, and Medicinal and veterinary uses. In this case, a greater knowledge of palm use could be interpreted as a function of a person's attitude toward the surrounding environment. An informant curious about his or her environment, with a commercial and experimental attitude, would be more likely to have a good knowledge of plants that can be potentially useful, and this knowledge would be reflected in a higher standard of living in the long run, especially in communities where agricultural products are not very diverse (Byg and Balslev 2001). We found no association between wealth and TK in the northern Andes, probably because this is the region where communities are more densely populated, have greater infrastructure development, and are well connected to commercial centers. For these reasons, the factors we evaluated as indicators of purchasing power did not reflect the wealth of people as well as in the other subregions.

Although our analyses are based only on palms, the most commonly cited plant family in neotropical ethnobotany and a keystone group for the subsistence of local people (Macía et al. 2011), for other plant families, we also expect a highly localized association between socioeconomic factors and TK. Our assessment indicates that regional-scale research and application of a standard method can efficiently help unravel these patterns.

\section{CONCLUSIONS}

We have shown that there are no regional patterns in the predictive power of the evaluated socioeconomic factors, and that their association with palm-use knowledge is highly localized. The differences found in the influence of socioeconomic factors reflect how highly variable and dynamic knowledge is. Most socioeconomic factors evaluated showed an association with TK in the lowlands (Amazon and Chocó), although with different trends, unlike the Andes, where the effect was very small. Although it seems logical that the socioeconomic factors evaluated should display a localized influence, our study highlights that generalizations made from analyzing these types of factors can lead to erroneous conclusions if applied without taking the characteristics and particularities of each place into account. We argue that understanding the heterogeneity of knowledge within a given area is crucial to designing conservation practices that build on the intricate links between knowledge, practices, and institutional context. These findings provide a strong argument for the conservation of TK using local strategies that consider all these possible variations and influence.

Responses to this article can be read online at: http://www.ecologyandsociety.org/issues/responses. $\mathrm{php} / 6934$

\begin{abstract}
Acknowledgments:
We express our deep gratitude to the 2050 kind and selfless people who agreed to share their time and knowledge with us. The collaboration of representatives of regional and local organizations of the 53 communities visited was essential to obtain work permits. We thank the Instituto de Ciencias Naturales at Universidad Nacional de Colombia, Pontificia Universidad Católica del Ecuador, Universidad Nacionál Mayor de San Marcos, and the Instituto para el desarrollo local y la conservación de la diversidad biológica y cultural andino amazónica (INBIA) in Peru, the Universidad Mayor de San Andrés in Bolivia, and the William L. Brown Center at the Missouri Botanical Garden for devoting resources and efforts to facilitate our work. Special thanks to Erika Blacutt, Carolina Tellez, Carlos Vega, Juan Carlos Copete, Marybel Soto, Lina Camelo, and Mateo Jaimes for their invaluable assistance in data collection in the field, and Luis Marconi for his statistical recommendations. This study was funded by the European Union 7th Framework Programme (contract 212631), the Russel E. Train Education for Nature Program of the $W W F$, and the Anne $S$. Chatham Fellowship of the Garden Clubs of America, for which we are grateful.
\end{abstract}

\section{LITERATURE CITED}

Alburquerque, U. P., and P. Muniz de Medeiros. 2012. Systematic reviews and meta-analysis applied to ethnobiological research. Ethnobiology and Conservation 1:6.

Arnold, J. E. M., and M. Ruiz Pérez. 2001. Can non-timber forest products match tropical forest conservation and development objectives? Ecological Economics 39:437-447. http://dx.doi. org/10.1016/S0921-8009(01)00236-1

Balick, M. J. 1984. Ethnobotany of palms in the neotropics. Advances in Economic Botany 1:923.

Balslev, H., T. R. Knudsen, A. Byg, M. Kronborg, and C. Grandez. 2010. Traditional knowledge, use, and management of Aphandra natalia (Arecaceae) in Amazonian Peru. Economic Botany 64(1):55-67. http://dx.doi.org/10.1007/s12231-009-9105-4

Beck, S. G., T. J. Killeen, and E. García. 1993. Vegetación de Bolivia. Pages 6-24 in T. J. Killeen, E. García, and S. G. Beck, editors. Guía de árboles de Bolivia. Herbario Nacional de Bolivia, Missouri Botanical Garden, La Paz, Bolivia.

Benz, B. F., J. E. Cevallos, F. M. Santana, J. A. Rosales, and S. M. Graf. 2000. Losing knowledge about plant use in the Sierra de Mazatlan Biosphere Reserve, Mexico. Economic Botany 54 (2):183-191. http://dx.doi.org/10.1007/BF02907821 
Berkes, F., J. Colding, and C. Folke. 2000. Rediscovery of traditional ecological knowledge as adaptive management. Ecological Applications 10(5): 1251-1262. http://dx.doi. org/10.1890/1051-0761(2000)010[1251:ROTEKA]2.0.CO;2

Borchsenius, F., H. Borgtoft, and H. Balslev. 1998. Manual to the palms of Ecuador. AUU Reports 37:12-17.

Brokamp, G., N. Valderrama, M. Mittelbach, C. A. Grandez, A. S. Barfod, and M. Weigend. 2011. Trade in palm products in northwestern South America. Botanical Review 77(4):571-606. http://dx.doi.org/10.1007/s12229-011-9087-7

Brosi, B. J., M. J. Balick, R. Wolkow, R. Lee, M. Kostka, W. Raynor, R. Gallen, A. Raynor, P. Raynor, and D. Lee Ling. 2007. Cultural erosion and biodiversity: canoe-making knowledge in Pohnpei, Micronesia. Conservation Biology 21(3):875-879. http:// dx.doi.org/10.1111/j.1523-1739.2007.00654.X

Bryk, A. S., and Raudenbush. 1992. Hierarchical linear models. Sage, Thousand Oaks, California, USA.

Byg, A. 2004. Humans and plants of the rain forest: factors affecting local knowledge and use of plants. Dissertation. Department of Systematic, University of Aarhus, Denmark.

Byg, A., and H. Balslev. 2001. Diversity and use of palms in Zahamena, eastern Madagascar. Biodiversity \& Conservation 10:951-970. http://dx.doi.org/10.1023/A:1016640713643

Byg, A., and H. Balslev. 2004. Factors affecting local knowledge of palms in Nangaritza Valley in South-Eastern Ecuador. Journal of Ethnobiology 24(2):255-278.

Byg, A., and H. Balslev. 2006. Palms in indigenous and settler communities in southeastern Ecuador: farmers' perceptions and cultivation practices. Agroforestry Systems 67:147-158. http://dx. doi.org/10.1007/s10457-005-1704-1

Byg, A., J. Vormisto, and H. Balslev. 2007. Influence of diversity and road access on palm extraction at landscape scale in SE Ecuador. Biodiversity and Conservation 16:631-642. http://dx.doi. org/10.1007/s10531-005-1342-y

Caballero, R. 1995. La Etnobotánica en las comunidades negras e indígenas del delta del rîo Patía. Programa de investigación, proyecto bosque de Guandal/PNUD Colombia 89.

Cámara-Leret, R., N. Paniagua-Zambrana, H. Balslev, and M. J. Macía. 2014. Ethnobotanical knowledge is vastly underdocumented in northwestern South America. PLoS ONE 9(1): e85794. http://dx.doi.org/10.1371/journal.pone.0085794

Cámara-Leret, R., N. Paniagua-Zambrana, and M. J. Macía. 2012. Standard protocol for gathering palm ethnobotanical data and socioeconomic variables across the tropics. Pages 41-72 in B. Ponman and R. W. Bussmann, editors. Medicinal plants and the legacy of Richard E. Schultes. Proceedings of the Botany 2011 Symposium Honoring Richard E Schultes. Graficart, Trujillo, Peru.

Campos, M. T., and C. Ehringhaus. 2003. Plant virtues are in the eyes of the beholders: a comparison of known palm uses among indigenous and folk communities of southwestern Amazonia. Economic Botany 57(3):324-344.

Cook, F. E. 1995. Economic botany data collection standard. Royal Botanic Gardens, Kew, Surrey, UK.
Coomes, O. T. 1996. Income formation among Amazonian peasant households in northeastern Peru: empirical observations and implications for market-oriented conservation. Yearbook, Conference of Latin Americanist Geographers 22:51-64.

Coomes, O. T., and B. L. Barham. 1997. Rain forest extraction and conservation in Amazonia. Geographical Journal 163:180188. http://dx.doi.org/10.2307/3060181

Figueiredo, G. M., H. F. Leitão-Filho, and A. Begossi. 1993. Ethnobotany of Atlantic forest coastal communities: diversity of plant uses in Gamboa (Itacuruçá Island, Brazil). Human Ecology 21:419-430. http://dx.doi.org/10.1007/BF00891142

Galeano, G. 2000. Forest use at the Pacific coast of Chocó, Colombia: a quantitative approach. Economic Botany 54(3):358376. http://dx.doi.org/10.1007/BF02864787

Galeano, G., and R. Bernal. 2010. Palmas de Colombia: Guía de campo. Instituto de Ciencias Naturales, Facultad de Ciencias, Universidad Nacional de Colombia, Bogotá, Colombia.

Godoy, R., and M. Contreras. 2001. A comparative study of education and tropical deforestation among lowland Bolivian Amerindians: forest values, environmental externality, and school subsidies. Economic Development and Cultural Change 49:555574. http://dx.doi.org/10.1086/452515

Godoy, R., V. Reyes-García, J. Broesch, I. C. Fitzpatrick, P. Giovarmini, M. R. M. Rodriguez, N. Jha, T. Huanca, W. R. Leonard, T. W. McDade, S. Tanner, and TAPS Bolivia Study Team. 2009. Long-term (secular) change of ethnobotanical knowledge of useful plants separating cohort and age effects. Journal of Anthropological Research 65(1):51-67.

Goldstein, H. 2003. Multilevel statistical models. Third edition. Kendall's Library of Statistics. Arnold, London, UK.

Gómez-Baggethun, E., and V. Reyes-García. 2013. Reinterpreting change in traditional ecological knowledge. Human Ecology 41 (4):643-647. http://dx.doi.org/10.1007/s10745-013-9577-9

Gray, C. L., R. E. Bilsborrow, J. L. Bremner, and F. Lu. 2008. Indigenous land use in the Ecuadorian Amazon: a cross-cultural and multilevel analysis. Human Ecology 36(1):97-109.http://dx. doi.org/10.1007/s10745-007-9141-6

Hanazaki, N., J. Y. Tamashiro, H. F. Leitão-Filho, and A. Begossi. 2000. Diversity of plant uses in two Caiçara communities from the Atlantic forest coast, Brazil. Biodiversity \& Conservation 9:597-615. http://dx.doi.org/10.1023/A:1008920301824

Heckler, M. 2002. Traditional ethnobotanical knowledge loss and gender among the Piaroa. Pages 532-548 in J. R. Stepp, F. S. Wundham, and R. K. Zarger, editors. Ehtnobiology and biocultural diversity. International Society of Ethnobiology, Athens, Georgia, USA.

Henderson, A., G. Galeano, and R. Bernal. 1995. Field guide to the palms of the Americas. Princeton University Press, New Jersey, USA.

Hunn, E. S. 2002. Evidence for the precocious acquisition of plant knowledge by Zapotec children. Pages 604-613 in J. R. Stepp, F. S. Wundham, and R. K. Zarger, editors. Ethnobiology and biocultural diversity. International Society of Ethnobiology, Athens, Georgia, USA. 
Huntington, H. P. 2000. Using traditional ecological knowledge in science: methods and applications. Ecological Applications 10 (5):1270-1274. http://dx.doi.org/10.1890/1051-0761(2000)010[1270: UTEKIS]2.0.CO;2

Jørgensen, P. M., and S. León-Yánez. 1999. Catalogue of the vascular plants of Ecuador. Monographs in Systematic Botany from the Missouri Botanical Garden 75:11181.

Ladio, A. H. 2001. The maintenance of wild edible plant gathering in a Mapuche community of Patagonia. Economic Botany 55 (2):243-254. http://dx.doi.org/10.1007/BF02864562

Ladio, A. H., and M. Lozada. 2001. Nontimber forest product use in two human populations from northwest Patagonia: a quantitative approach. Human Ecology 29:367-380. http://dx. doi.org/10.1023/A:1013199103440

Ladio, A. H., and M. Lozada. 2004. Patterns of use knowledge of wild edible plants in distinct ecological environments: a case study of a Mapuche community from northwestern Patagonia. Biodiversity \& Conservation 13:1153-1173. http://dx.doi. org/10.1023/B:BIOC.0000018150.79156.50

Lawrence, A., O. L. Philipps, A. Ismodes, M. López, S. Rose, D. Wood, and A. J. Farfan. 2005. Local values for harvested forest plants in Madre de Dios, Peru: towards a more contextualised interpretation of quantitative ethnobotanical data. Biodiversity \& Conservation 14:45-79. http://dx.doi.org/10.1007/s10531-005-4050-8

Luoga, E. J., E. T. F. Witkowski, and K. Balkwill. 2000. Differential utilization and ethnobotany of trees in Kitulanghalo Forest Reserve and surrounding communal lands, eastern Tanzania. Economic Botany 54(3):328-343. http://dx.doi. org/10.1007/BF02864785

Macía, M. J. 2004. Multiplicity in palm uses by the Huaorani of Amazonian Ecuador. Botanical Journal of the Linnean Society 144:149-159. http://dx.doi.org/10.1111/j.1095-8339.2003.00248. $\underline{\mathrm{x}}$

Macía, M. J., P. J. Armesilla, R. Cámara-Leret, N. PaniaguaZambrana, S. Villalba, H. Balslev, and M. Pardo-de-Santayana. 2011. Palm uses in northwestern South America: a quantitative review. Botanical Review 77(4):462-570. http://dx.doi.org/10.1007/ s12229-011-9086-8

Mackinson, S., and L. Nottestad. 1998. Points of view: combining local and scientific knowledge. Reviews in Fish Biology and Fisheries 8(4):481-490. http://dx.doi.org/10.1023/A:1008847106984

Moerman, D. E., R. W. Pemberton, and D. Kiefer. 1999. A comparative analysis of five medicinal floras. Journal of Ethnobiology 19(1):49-67.

Molares, S., and A. Ladio. 2009. Ethnobotanical review of the Mapuche medicinal flora: use patterns on a regional scale. Journal of Ethnopharmacology 122(2):251-260. http://dx.doi.org/10.1016/ j.jep.2009.01.003

Moraes, M. 2004. Flora de palmeras de Bolivia. Plural Editores, La Paz, Bolivia.

Ohmagari, K., and F. Berkes 1997. Transmission of indigenous knowledge and bush skills among the western James Bay Cree women of subarctic Canada. Human Ecology 25(2):197-222. http://dx.doi.org/10.1023/A:1021922105740
Paniagua Zambrana, N. Y., A. Byg, J.-C. Svenning, M. Moraes, C. Grandez, and H. Balslev. 2007. Diversity of palm uses in the western Amazon. Biodiversity and Conservation 16:2771-2787. http://dx.doi.org/10.1007/s10531-007-9218-y

Paniagua-Zambrana, N., M. J. Macía, and R. Cámara-Leret. 2010. Toma de datos etnobotánicos de palmeras y variables socioeconómicas en comunidades rurales. Ecología en Bolivia 45 (3):44-68.

Phillips, O., and A. H. Gentry. 1993. The useful plants of Tambopata, Peru: II. Additional hypothesis testing in quantitative ethnobotany. Economic Botany 47(1):33-43. http:// dx.doi.org/10.1007/BF02862204

Pintaud, J., G. Galeano, H. Balslev, R. Bernal, F. Borchsenius, E. Ferreira, J. de Granville, K. Mejía, B. Millán, M. Moraes, L. Noblick, F. W. Stauffer, and F. Kahn. 2008. Las palmeras de América del Sur: diversidad, distribución e historia evolutiva. Revista Peruana de Biología 15(1):729.

Prance, G. T., W. Balée, B. M. Boom, and R. L. Carneiro. 1987. Quantitative ethnobotany and the case for conservation in Amazonia. Conservation Biology 1:296-310. http://dx.doi. org/10.1111/j.1523-1739.1987.tb00050.x

Renner, S. S., H. Balslev, and L. B. Holm-Nielsen. 1990. Flowering plants of Amazonian Ecuador - a checklist. AAU Reports 24:1241 .

Reyes-García, V., N. Marti, T. McDade, S. Tanner, and V. Vadez. 2007. Concepts and methods in studies measuring individual ethnobotanical knowledge. Journal of Ethnobiology 27(2):182203. http://dx.doi.org/10.2993/0278-0771(2007)27[182:CAMISM] 2.0. $\mathrm{CO} ; 2$

Reyes-García, V., T. McDade, V. Vadez, T. Huanca, W. R. Leonard, S. Tanner, and R. Godoy. 2008. Non-market returns to traditional human capital: nutritional status and traditional knowledge in a native Amazonian society. Journal of Development Studies 44: 217-232. http://dx.doi.org/10.1080/00220380701789901

Reyes-García, V., V. Vadez, E. Byron, L. Apaza, W. R. Leonard, E. Perez, and D. Wilkie. 2005. Market economy and the loss of folk knowledge of plant uses: estimates from the Tsimane' of the Bolivian Amazon. Current Anthropology 46(4):651-656. http:// dx.doi.org/10.1086/432777

Saslis-Lagoudakis, C. H., E. M. Williamson, V. Savolainen, and J. A. Hawkins. 2011. Cross-cultural comparison of three medicinal floras and implications for bioprospecting strategies. Journal of Ethnopharmacology 135(2):476-487. http://dx.doi. org/10.1016/j.jep.2011.03.044

Scatena, F. N., R. T. Walker, A. K. Oyama Homma, A. J. de Conto, C. A. Palheta Rerreira, R. de Amorim Carvalho, A. C. Paula Neves da Rocha, A. I. Moreira dos Santos, and P. Mourao de Oliveira. 1996. Cropping and fallowing sequences of small farms in the "terra firme" landscape of the Brazilian Amazon: a case study from Santarem, Para. Ecological Economics 18:29-40. http://dx.doi.org/10.1016/0921-8009(95)00055-0

Shackeroff, J. M., and L. M. Campbell. 2007. Traditional ecological knowledge in conservation research: problems and prospects for their constructive engagement. Conservation and Society 5(3):343-360. 
Somnasang, P., and G. Moreno-Black. 2000. Knowing, gathering and eating: knowledge and attitudes about wild food in an Isan village in NE Thailand. Journal of Ethnobiology 20(2):197-216.

Stagegaard, J., M. Sørensen, and L. P. Kvist. 2002. Estimations of the importance of plant resources extracted by inhabitants of the Peruvian Amazon food plains. Perspectives in Plant Ecology Evolution and Systematics 5:103-122. http://dx.doi. org/10.1078/1433-8319-00026

Takasaki, Y., B. L. Barham, and O. T. Coomes. 2001. Amazonian peasants, rain forest use and income generation: the role of wealth and geographical factors. Society and Natural Resources 14:291308. http://dx.doi.org/10.1080/08941920151080237

Thiers, B. 2013. Index Herbariorum: a global directory of public herbaria and associated staff. New York Botanical Garden's Virtual Herbarium. http://sweetgum.nybg.org/ih/.

Vandebroek, I. 2010. The dual intracultural and intercultural relationship between medicinal plant knowledge and consensus. Economic Botany 64(4):303-317. http://dx.doi.org/10.1007/ $\underline{\text { s12231-010-9135-y }}$

Wiersum, K. F. 1997. Indigenous exploitation and management of tropical forest resources: an evolutionary continuum in forestpeople interactions. Agriculture, Ecosystems \& Environment 63:116. http://dx.doi.org/10.1016/S0167-8809(96)01124-3

Zarger, R. K. 2002. Acquisition and transmission of subsistence knowledge by Q'eqchi' Maya in Belize. Pages 592-603 in J. R. Stepp, F. S. Wyndham, and R. K. Zarger, editors. Ethnobiology and biocultural diversity. International Society of Ethnobiology, Athens, Georgia, USA.

Zent, S. 1999. The quandary of conserving ethnoecological knowledge - a Piaroa example. Pages 90-124 in T. L. Gragson and B. G. Blount, editors. Ethnoecology - knowledge, resources, and rights. University of Georgia Press, Athens, Georgia, USA.

Zent, S. 2001. Acculturation and ethnobotanical knowledge loss among the Piaroa of Venezuela: demonstration of a quantitative method for the empirical study of TEK change. Pages 190-211 in L. Maffi, editor. On Biocultural diversity: linking language, knowledge, and the environment. Smithsonian Institution Press, Washington, D.C., USA. 


\section{APPENDIX 1}

Characteristic of the 53 communities where 2050 people were interviewed about their knowledge of palm use in Northwestern South America (Colombia, Ecuador, Peru, and Bolivia).

(a) The information about the nearest town and the time it takes to reach to it was obtained from interviews with informants. The data represents the town and the time reported most frequently by the informants.

(b) Availability of electricity: (1) no electricity, (2) free electricity, (3) paid electricity. Access to education: (1) no school, (2) primary school, (3) secondary school, (4) community college or university. Access to healthcare: (1) without health post (only traditional medicine), (2) health post / community nurse, (3) health post / physician (4) local hospital.

Ecoregion - Country

Community (population)

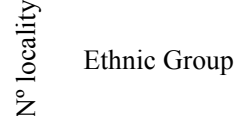

Multiethnic indigenous

Multiethnic indigenous

A Multiethnic indigenous

Multiethnic indigenous

Tikuna

C Cofan

C Cofan

C Cofan

D Achuar

D Achuar

D Achuar

E Cocama

F Mestizo
Accessibility $^{(a)}$

Linguistic family

Nearest town (Distance in

hr.)

Type access

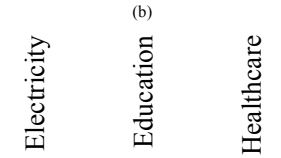

Number of informants

$\begin{array}{lll}\text { Multiethnic } & \text { La Pedrera (1.5) } & \text { Fluvial } \\ \text { Multiethnic } & \text { La Pedrera (1) } & \text { Fluvial } \\ \text { Multiethnic } & \text { La Pedrera (0.75) } & \text { Fluvial } \\ \text { Multiethnic } & \text { La Pedrera (0.33) } & \text { Fluvial } \\ \text { Language isolate } & \text { Leticia (6) } & \text { Fluvial } \\ & & \\ \text { Chibchan (Barbacoan) } & \text { Lago Agrio (6) } & \text { Fluvial } \\ \text { Chibchan (Barbacoan) } & \text { Lago Agrio (6) } & \text { Fluvial } \\ \text { Chibchan (Barbacoan) } & \text { Lago Agrio (0.33) } & \text { Fluvial } \\ \text { Jivaroan } & \text { Kapawi (3) } & \text { Fluvial } \\ \text { Jivaroan } & \text { Kapawi (0) } & \text { Fluvial } \\ \text { Jivaroan } & \text { Kusutko (0) } & \text { Fluvial } \\ & & \\ \text { Tupi } & & \text { Fluvial } \\ \text { Castellano } & \text { Nauta (18) } & \text { Fluvial }\end{array}$

$$
\text { Peru }
$$

13 El Chino (550)

Castellano

Fluvial 


$\begin{array}{ll}4 & \text { Santa Ana (450) } \\ 5 & \text { Yamayakat (1000) } \\ 6 & \text { Cusu Chico (150) } \\ 17 & \text { Nueva Samaria (80) } \\ 8 & \text { Villa Santiago (120) } \\ 9 & \text { Santa Rosa (500) } \\ 20 & \text { Unión Progreso (300) } \\ 21 & \text { Palma Real (300) } \\ & \text { Bolivia } \\ 22 & \text { Santa María (250) } \\ 23 & 26 \text { de Octubre (180) } \\ 24 & \text { Alto Ivón (500) } \\ 25 & \text { Motacuzal (30) } \\ 26 & \text { San Benito (90) } \\ 27 & \text { Sanandita (60) } \\ 28 & \text { San Antonio (90) } \\ 29 & \text { Secejsama (100) } \\ 30 & 25 \text { de Mayo (100) } \\ 31 & \text { Buena Vista (240) } \\ 32 & \text { San Isidro (50) } \\ 33 & \text { San Silvestre (100) } \\ 34 & \text { Sta. Rosa de Maravilla (50) }\end{array}$

\section{Nothern Andes}

\section{Colombia}

35 Sibundoy (13000)

6 Santiago (5800)

37 Juisanoy (2000)

Ecuador

38 Nanegalito (3200)

39 Mindo (1500)

\section{Southern Ande}

Peru

40 Lamas Wayku (1200)

41 Aviación (300)

\section{Bolivia}

42 Irimo (350)

43 Munaypata (80)

44 Pucasucho (280)
G Mestizo

$\mathrm{H}$ Aguaruna

$\mathrm{H}$ Aguaruna

$\mathrm{H}$ Aguaruna

I Mestizo-Amakaeri

I Mestizo

I Mestizo

J Ese Eja

K Mestizo

K Mestizo

L Chacobo

L Chacobo

M Yuracaré

M Yuracaré

M Yuracaré

M Yuracaré

N Mestizo-Tacana

N Mestizo-Tacana

$\mathrm{N}$ Leco-Tacana

$\mathrm{N}$ Tacana

$\mathrm{N}$ Mestizo-Tacana

\section{O Camsá \\ $P \quad$ Inga}

$P \quad$ Inga

\section{Q Mestizo}

R Mestizo

\section{S Chanka}

S Chanka

T Leco

$\mathrm{T}$ Leco

$\mathrm{T}$ Leco

Castellano
Jivaroan
Jivaroan
Jivaroan
Castellano
Castellano
Castellano
Tacanan
Castellano
Castellano
Panoan
Panoan
Language isolate
Language isolate
Language isolate
Language isolate
Castellano-Tacanan
Castellano-Tacanan
Language isolate-Tacanan
Tacanan
Castellano-Tacanan

Iquitos (5)

Imacita (0.25)

Imacita (1)

Imacita (0.75)

Masuko (0.5)

Masuko (1)

Puerto Maldonado (1)

Puerto Maldonado (4)

Riberalta (1)

Riberalta (1)

Riberalta (4)

Riberalta (3.5)

San Gabriel (1.66)

San Gabriel (1.5)

Ichoa (2)

Isinuta (1.5)

San Buenaventura (1)

San Buenaventura (0.75)

San Buenaventura (0.5)

San Buenaventura (1.5)

San Buenaventura (1.75)

Sibundoy (0)

Santiago (0)

Santiago $(0.5)$

\section{Quito (4)}

Quito (3)

Lamas (0.25)

Lamas (2.5)

Apolo (3)

Apolo (1.5)

Apolo (4)
Fluvial

Fluvial

Fluvial

Fluvial

armac

Tarmac

Tarmac

Fluvial

Loose surface road

Road

Road

Fluvial/road

Fluvial/road

Road

Road

Road

Road

Road

Road

\section{Tarmac}

Tarmac

Loose surface road

Tarmac

Tarmac

Tarmac

Loose surface road

Loose surface road

Loose surface road

Loose surface road
13

14

\begin{abstract}
a
\end{abstract}


45 Illipanayuyo (150)

46 Santo Domingo (220)

47 Correo (260)

Chocó

Colombia

48 Puerto Pervel (1500)

49 Aguacate (312)

50 Villanueva (200)

\section{Ecuador}

51 Puerto Quito (1500)

52 Chigüilpe (130)

53 Peripa (130)
U Leco

U Leco

U Leco

$\begin{array}{cl}\mathrm{V} & \text { Afro-american } \\ \mathrm{W} & \text { Emberá } \\ \mathrm{W} & \text { Emberá } \\ & \\ \mathrm{X} & \text { Mestizo } \\ \mathrm{Y} & \text { Tsáchila } \\ \mathrm{Y} & \text { Tsáchila }\end{array}$

Language isolate

Language isolate

Language isolate

Castellano

Chocó

Chocó

Castellano

Tsafiki (Barbacoan)

Tsafiki (Barbacoan)
Apolo (4)

Apolo (7)

Apolo (7)

Quibdo (2)

La Playa (24)

La Playa (24)

Santo Domingo (0.5)

Santo Domingo (0.5)

Santo Domingo (0.5)
Loose surface road

Loose surface road

Loose surface road

Tarmac

Fluvial

Fluvial

Tarmac

Tarmac

Tarmac
24

33

86

44 


\section{APPENDIX 2}

Distribution of the 2050 informants interviewed in 25 localities (letters) of northwestern South America across the 14 socioeconomic variables evaluated, in accordance with the description in Table 2. For the continuous variables the information is given as Mean \pm SD.

\section{SOCIOECONOMIC FACTOR AT PERSONAL LEVEL}

\begin{tabular}{|c|c|c|c|c|c|c|c|c|c|c|c|c|c|c|c|c|c|c|}
\hline \multirow[b]{2}{*}{ Sub-region - Localities } & \multicolumn{2}{|c|}{ Gender } & \multicolumn{5}{|c|}{ Age } & \multicolumn{3}{|c|}{ Ethnicity } & \multirow{2}{*}{$\begin{array}{c}\text { Education } \\
\text { Mean } \pm \text { SD }\end{array}$} & \multicolumn{3}{|c|}{$\begin{array}{l}\text { Language } \\
\text { spoken }\end{array}$} & \multicolumn{3}{|c|}{ Migratory status } & \multirow{2}{*}{$\begin{array}{c}\text { Time in residence } \\
\quad \text { Mean } \pm \text { SD }\end{array}$} \\
\hline & 1 & 2 & 1 & 2 & 3 & 4 & 5 & 1 & 2 & 3 & & 1 & 2 & 3 & 1 & 2 & 3 & \\
\hline Northern Amazon & 153 & 147 & 86 & 79 & 55 & 36 & 44 & 299 & 1 & - & $4.9 \pm 4.2$ & 15 & 23 & 262 & 241 & 58 & 1 & $30.0 \pm 16.5$ \\
\hline $\mathrm{A}$ & 42 & 23 & 17 & 17 & 13 & 6 & 12 & 64 & 1 & - & $4.4 \pm 3.7$ & - & 20 & 45 & 37 & 28 & - & $19.1 \pm 10.1$ \\
\hline $\mathrm{B}$ & 42 & 46 & 20 & 20 & 17 & 15 & 16 & 88 & - & - & $5.2 \pm 4.0$ & 1 & - & 87 & 80 & 7 & 1 & $38.7 \pm 15.3$ \\
\hline $\mathrm{C}$ & 38 & 44 & 26 & 21 & 13 & 8 & 14 & 82 & - & - & $4.1 \pm 3.9$ & 9 & 3 & 70 & 81 & 1 & - & $34.6 \pm 17.6$ \\
\hline Southern Amazon & 415 & 413 & 235 & 190 & 175 & 106 & 122 & 438 & 390 & - & $5.0 \pm 3.5$ & 19 & 393 & 416 & 510 & 208 & 110 & $27.6 \pm 16.8$ \\
\hline $\mathrm{E}$ & 44 & 43 & 19 & 17 & 24 & 10 & 17 & 49 & 38 & - & $5.4 \pm 3.4$ & - & 82 & 5 & 37 & 47 & 3 & $27.2 \pm 19.6$ \\
\hline F & 34 & 45 & 26 & 23 & 12 & 9 & 9 & - & 79 & - & $4.6 \pm 2.4$ & - & 79 & - & 39 & 39 & 1 & $27.6 \pm 12.4$ \\
\hline G & 39 & 50 & 22 & 21 & 19 & 11 & 16 & - & 89 & - & $5.3 \pm 3.0$ & - & 89 & - & 67 & 22 & - & $37.0 \pm 18.1$ \\
\hline $\mathrm{H}$ & 35 & 34 & 21 & 17 & 12 & 11 & 8 & 69 & - & - & $6.4 \pm 4.4$ & 6 & 2 & 61 & 69 & - & - & $30.8 \pm 14.3$ \\
\hline I & 45 & 33 & 22 & 14 & 16 & 11 & 15 & 12 & 66 & - & $5.9 \pm 4.0$ & 1 & 23 & 54 & 22 & 8 & 48 & $26.1 \pm 17.2$ \\
\hline $\mathrm{K}$ & 39 & 40 & 10 & 18 & 19 & 14 & 18 & 1 & 78 & - & $4.6 \pm 3.5$ & - & 72 & 7 & 5 & 70 & 4 & $16.0 \pm 12.4$ \\
\hline $\mathrm{L}$ & 40 & 40 & 37 & 21 & 13 & 6 & 3 & 80 & - & - & $4.3 \pm 4.6$ & 12 & 1 & 67 & 79 & 1 & - & $24.5 \pm 13.4$ \\
\hline M & 32 & 28 & 18 & 16 & 14 & 4 & 8 & 58 & 2 & - & $3.1 \pm 2.7$ & - & 1 & 59 & 39 & 8 & 13 & $19.0 \pm 10.5$ \\
\hline $\mathrm{N}$ & 69 & 49 & 25 & 21 & 33 & 20 & 19 & 83 & 35 & - & $5.3 \pm 3.2$ & - & 43 & 75 & 73 & 6 & 39 & $28.4 \pm 17.7$ \\
\hline Northern Andes & 148 & 194 & 110 & 75 & 53 & 42 & 62 & 167 & 172 & 3 & $7.7 \pm 4.6$ & - & 211 & 131 & 228 & 52 & 62 & $33.1 \pm 21.4$ \\
\hline $\mathrm{O}$ & 30 & 52 & 31 & 19 & 11 & 6 & 15 & 82 & - & - & $8.4 \pm 5.1$ & - & 13 & 69 & 82 & - & - & $39.9 \pm 18.6$ \\
\hline
\end{tabular}




$\begin{array}{ccccccccccccccccccc}\mathrm{P} & 34 & 53 & 24 & 17 & 13 & 14 & 19 & 85 & 2 & - & 6.5 \pm 4.2 & - & 25 & 62 & 87 & - & - & 42.7 \pm 19.7 \\ \mathrm{Q} & 36 & 50 & 26 & 19 & 16 & 10 & 15 & - & 86 & - & 7.5 \pm 4.2 & - & 86 & - & 24 & 36 & 26 & 23.0 \pm 18.5 \\ \mathrm{R} & 48 & 39 & 29 & 20 & 13 & 12 & 13 & - & 84 & 3 & 8.3 \pm 4.7 & - & 87 & - & 35 & 16 & 36 & 26.9 \pm 21.9 \\ \text { Southern Andes } & \mathbf{1 4 9} & \mathbf{1 1 9} & \mathbf{5 8} & \mathbf{6 3} & \mathbf{7 3} & \mathbf{3 6} & \mathbf{3 8} & \mathbf{2 5 2} & \mathbf{1 6} & - & \mathbf{4 . 7 \pm 3 . 4} & \mathbf{4} & \mathbf{9} & \mathbf{2 5 5} & \mathbf{2 4 8} & \mathbf{2} & \mathbf{1 8} & \mathbf{3 6 . 0 \pm 1 8 . 4} \\ \mathrm{S} & 54 & 36 & 14 & 16 & 27 & 14 & 19 & 86 & 4 & - & 3.1 \pm 3.1 & 4 & 4 & 82 & 85 & 1 & 4 & 46.0 \pm 17.6 \\ \mathrm{~T} & 50 & 39 & 26 & 22 & 23 & 7 & 11 & 89 & - & - & 6.0 \pm 2.9 & - & 3 & 86 & 88 & 1 & - & 32.4 \pm 14.6 \\ \mathrm{U} & 45 & 44 & 18 & 25 & 23 & 15 & 8 & 77 & 12 & - & 5.0 \pm 3.6 & - & 2 & 87 & 75 & - & 14 & 29.3 \pm 18.3 \\ \text { Chocó } & \mathbf{1 5 2} & \mathbf{1 6 0} & \mathbf{9 1} & \mathbf{6 4} & \mathbf{5 0} & \mathbf{5 3} & \mathbf{5 4} & \mathbf{1 3 8} & \mathbf{8 7} & \mathbf{8 7} & \mathbf{5 . 2 \pm 4 . 8} & \mathbf{1 2} & \mathbf{1 9 7} & \mathbf{1 0 3} & \mathbf{2 4 7} & \mathbf{1 9} & \mathbf{4 6} & \mathbf{2 5 . 6 \pm 1 7 . 6} \\ \mathrm{V} & 47 & 39 & 18 & 14 & 19 & 16 & 19 & - & - & 86 & 5.9 \pm 4.9 & - & 86 & - & 84 & 1 & 1 & 29.4 \pm 12.2 \\ \mathrm{~W} & 42 & 46 & 32 & 23 & 14 & 14 & 5 & 88 & - & - & 1.8 \pm 2.4 & 12 & 23 & 53 & 85 & 3 & - & 14.8 \pm 17.6 \\ \mathrm{X} & 41 & 47 & 30 & 16 & 7 & 15 & 20 & - & 87 & 1 & 7.6 \pm 4.3 & - & 88 & - & 30 & 13 & 45 & 25.0 \pm 14.6 \\ \mathrm{Y} & 22 & 28 & 11 & 11 & 10 & 8 & 10 & 50 & - & - & 5.5 \pm 5.1 & - & - & 50 & 48 & 2 & - & 39.4 \pm 18.7\end{array}$

\section{SOCIOECONOMIC FACTOR AT HOUSEHOLD LEVEL}

\begin{tabular}{|c|c|c|c|c|c|c|c|c|c|c|c|c|c|c|c|c|}
\hline \multirow[b]{2}{*}{ Sub-region - Localities } & \multirow{2}{*}{$\begin{array}{l}\text { Size family } \\
\text { Mean } \pm \text { SD }\end{array}$} & \multicolumn{3}{|c|}{ Farm animal } & \multirow{2}{*}{$\begin{array}{c}\text { Farm size } \\
\text { Mean } \pm \text { SD }\end{array}$} & \multicolumn{3}{|c|}{ Tools } & \multicolumn{4}{|c|}{ Transport } & House size & \multicolumn{3}{|c|}{$\begin{array}{c}\text { House construction } \\
\text { material }\end{array}$} \\
\hline & & 1 & 2 & 3 & & 1 & 2 & 3 & 1 & 2 & 3 & 4 & Mean \pm SD & 1 & 2 & 3 \\
\hline Northern Amazon & $4.7 \pm 3.3$ & 163 & 135 & 2 & $0.7 \pm 0.7$ & 212 & 75 & 13 & 109 & 146 & 24 & 21 & $59.2 \pm 37.6$ & 122 & 9 & 169 \\
\hline A & $4.9 \pm 2.8$ & 32 & 32 & 1 & $1.2 \pm 0.8$ & 39 & 26 & - & 23 & 25 & 15 & 2 & $63.6 \pm 42.1$ & 11 & 3 & 51 \\
\hline $\mathrm{B}$ & $4.2 \pm 3.2$ & 33 & 55 & - & $0.5 \pm 0.3$ & 80 & 5 & 3 & 25 & 55 & 6 & 2 & $57.3 \pm 33.2$ & 43 & 6 & 39 \\
\hline $\mathrm{C}$ & $5.2 \pm 3.5$ & 47 & 35 & - & $0.9 \pm 0.8$ & 56 & 16 & 10 & 46 & 19 & - & 17 & $68.6 \pm 45.4$ & 5 & - & 77 \\
\hline Southern Amazon & $4.2 \pm 3.0$ & 90 & 679 & 59 & $1.6 \pm 1.4$ & 91 & 557 & 180 & 236 & 295 & 272 & 25 & $64.2 \pm 59.9$ & 634 & 18 & 176 \\
\hline $\mathrm{E}$ & $5.2 \pm 3.5$ & 7 & 80 & - & $1.4 \pm 0.8$ & 2 & 66 & 19 & 4 & 34 & 45 & 4 & $67.4 \pm 39.5$ & 75 & - & 12 \\
\hline F & $3.9 \pm 2.7$ & 5 & 72 & 2 & $1.4 \pm 1.3$ & - & 77 & 2 & 2 & 35 & 40 & 2 & $100.6 \pm 57.2$ & 77 & - & 2 \\
\hline G & $4.6 \pm 3.1$ & 12 & 77 & - & $2.0 \pm 2.2$ & 22 & 62 & 5 & 23 & 37 & 29 & - & $71.2 \pm 31.6$ & 73 & - & 16 \\
\hline $\mathrm{H}$ & $4.3 \pm 3.3$ & 4 & 65 & - & $0.9 \pm 0.6$ & 34 & 34 & 1 & 59 & 2 & 5 & 3 & $44.7 \pm 27.4$ & 49 & 2 & 18 \\
\hline
\end{tabular}




\begin{tabular}{|c|c|c|c|c|c|c|c|c|c|c|c|c|c|c|c|c|}
\hline I & $3.0 \pm 2.5$ & 7 & 61 & 10 & $2.3 \pm 1.8$ & 14 & 9 & 55 & 32 & - & 39 & 7 & $109.3 \pm 153.8$ & 22 & 11 & 45 \\
\hline $\mathrm{J}$ & $3.2 \pm 2.1$ & 23 & 63 & 3 & $1.1 \pm 0.9$ & 8 & 49 & 32 & 30 & 31 & 27 & 1 & $41.2 \pm 22.8$ & 63 & 1 & 25 \\
\hline K & $6.6 \pm 3.4$ & 6 & 68 & 5 & $2.5 \pm 1.5$ & 1 & 61 & 17 & 16 & 24 & 35 & 4 & $60.0 \pm 22.9$ & 71 & 4 & 4 \\
\hline $\mathrm{L}$ & $4.4 \pm 3.0$ & 1 & 77 & 2 & $1.7 \pm 0.8$ & 2 & 78 & - & 6 & 29 & 45 & - & $59.8 \pm 27.3$ & 75 & - & 5 \\
\hline M & $3.3 \pm 2.6$ & 19 & 41 & - & $1.0 \pm 0.1$ & 4 & 11 & 45 & 29 & 29 & 2 & - & $46.0 \pm 21.4$ & 17 & - & 43 \\
\hline $\mathrm{N}$ & $3.3 \pm 1.6$ & 6 & 75 & 37 & $1.8 \pm 1.0$ & 4 & 110 & 4 & 35 & 74 & 5 & 4 & $46.2 \pm 19.9$ & 112 & - & 6 \\
\hline Northern Andes & $3.7 \pm 3.2$ & 236 & 93 & 13 & $0.5 \pm 2.0$ & 339 & 1 & 2 & 284 & 25 & 14 & 19 & $81.2 \pm 47.2$ & - & 306 & 36 \\
\hline $\mathrm{O}$ & $3.4 \pm 3.2$ & 55 & 27 & - & $0.5 \pm 0.6$ & 82 & - & - & 50 & 20 & 11 & 1 & $86.2 \pm 43.4$ & - & 80 & 2 \\
\hline$P$ & $4.1 \pm 3.3$ & 40 & 36 & 11 & $0.3 \pm 0.4$ & 87 & - & - & 77 & 5 & 3 & 2 & $81.2 \pm 34.0$ & - & 87 & - \\
\hline Q & $3.8 \pm 3.1$ & 70 & 16 & - & $0.8 \pm 2.8$ & 83 & 1 & 2 & 78 & - & - & 8 & $73.5 \pm 50.9$ & - & 70 & 16 \\
\hline $\mathrm{R}$ & $3.5 \pm 3.2$ & 71 & 14 & 2 & $0.6 \pm 2.7$ & 87 & - & - & 79 & - & - & 8 & $84.0 \pm 57.0$ & - & 69 & 18 \\
\hline Southern Andes & $4.7 \pm 3.0$ & 20 & 209 & 39 & $2.0 \pm 1.8$ & 81 & 128 & 59 & 210 & 51 & 2 & 5 & $56.3 \pm 35.9$ & 71 & 13 & 184 \\
\hline $\mathrm{S}$ & $4.0 \pm 2.7$ & 5 & 78 & 7 & $1.8 \pm 1.5$ & 26 & 61 & 3 & 88 & - & 1 & 1 & $83.1 \pm 46.2$ & 2 & 5 & 83 \\
\hline $\mathrm{T}$ & $5.2 \pm 3.1$ & 7 & 63 & 19 & $2.2 \pm 1.5$ & 14 & 50 & 25 & 56 & 33 & - & - & $45.4 \pm 15.2$ & 38 & 2 & 49 \\
\hline $\mathrm{U}$ & $4.8 \pm 3.0$ & 8 & 68 & 13 & $2.2 \pm 2.3$ & 41 & 17 & 31 & 66 & 18 & 1 & 4 & $40.1 \pm 20.0$ & 31 & 6 & 52 \\
\hline Chocó & $3.8 \pm 3.2$ & 87 & 215 & 10 & $1.8 \pm 5.2$ & 299 & 9 & 4 & 185 & 100 & 17 & 10 & $54 \pm 31.1$ & 25 & 210 & 77 \\
\hline $\mathrm{V}$ & $4.2 \pm 3.3$ & 21 & 61 & 4 & $0.4 \pm 0.7$ & 84 & 1 & 1 & 43 & 28 & 12 & 3 & $54.9 \pm 17.2$ & 1 & 79 & 6 \\
\hline W & $4.4 \pm 3.4$ & 12 & 72 & 4 & $0.9 \pm 1.0$ & 83 & 5 & - & 16 & 72 & - & - & $36.4 \pm 18.2$ & 18 & - & 70 \\
\hline $\mathrm{X}$ & $3.2 \pm 2.9$ & 42 & 45 & 1 & $2.3 \pm 8.7$ & 88 & - & - & 85 & - & 3 & - & $65.3 \pm 41.0$ & - & 88 & - \\
\hline $\mathrm{Y}$ & $3.7 \pm 3.0$ & 12 & 37 & 1 & $4.8 \pm 4.7$ & 44 & 3 & 3 & 41 & - & 2 & 7 & $63.3 \pm 34.2$ & 6 & 43 & 1 \\
\hline
\end{tabular}

